NBER WORKING PAPER SERIES

\title{
EXPERIMENTAL EVIDENCE ON THE EFFECTS OF HOME COMPUTERS ON ACADEMIC ACHIEVEMENT AMONG SCHOOLCHILDREN
}

\author{
Robert W. Fairlie \\ Jonathan Robinson \\ Working Paper 19060 \\ http://www.nber.org/papers/w19060
NATIONAL BUREAU OF ECONOMIC RESEARCH
1050 Massachusetts Avenue
Cambridge, MA 02138 \\ May 2013
}

We thank Computers for Classrooms, Inc., the ZeroDivide Foundation, and the NET Institute (www.NETinst.org) for generous funding for the project. We thank David Card, Tarjei Havnes, Oded Gurantz, and participants at seminars and workshops at UC Berkeley, SOLE, the MacArthur Foundation and the CESifo ICT Conference for comments and suggestions. We also thank Bruce Besnard, Jennifer Bevers, John Bohannon, Linda Coleman, Brian Gault, Reg Govan, Rebecka Hagerty, Kathleen Hannah-Chambas, David Jansen, Cynthia Kampf, Gina Lanphier, Linda Leonard, Kurt Madden, Lee McPeak, Stephen Morris, Joanne Parsley, Richard Pascual, Jeanette Sanchez, Zenae Scott, Tom Sharp, and many others for administering the program in schools. We thank Shilpa Aggarwal, Julian Caballero, David Castaneda, James Chiu, Samantha Grunberg, Keith Henwood, Cody Kennedy, Nicole Mendoza, Nick Parker, Miranda Schirmer, Glen Wolf and Heidi Wu for research assistance. Finally, special thanks go to Pat Furr for donating many computers for the study and distributing computers to schools. The views expressed herein are those of the authors and do not necessarily reflect the views of the National Bureau of Economic Research.

NBER working papers are circulated for discussion and comment purposes. They have not been peerreviewed or been subject to the review by the NBER Board of Directors that accompanies official NBER publications.

(C) 2013 by Robert W. Fairlie and Jonathan Robinson. All rights reserved. Short sections of text, not to exceed two paragraphs, may be quoted without explicit permission provided that full credit, including (C) notice, is given to the source. 
Experimental Evidence on the Effects of Home Computers on Academic Achievement among Schoolchildren

Robert W. Fairlie and Jonathan Robinson

NBER Working Paper No. 19060

May 2013

JEL No. I24

\begin{abstract}
Computers are an important part of modern education, yet many schoolchildren lack access to a computer at home. We test whether this impedes educational achievement by conducting the largest-ever field experiment that randomly provides free home computers to students. Although computer ownership and use increased substantially, we find no effects on any educational outcomes, including grades, test scores, credits earned, attendance and disciplinary actions. Our estimates are precise enough to rule out even modestly-sized positive or negative impacts. The estimated null effect is consistent with survey evidence showing no change in homework time or other "intermediate" inputs in education.
\end{abstract}

Robert W. Fairlie

Department of Economics

University of California, Santa Cruz

Santa Cruz, CA 95064

rfairlie@ucsc.edu

Jonathan Robinson

Department of Economics

University of California, Santa Cruz

457 Engineering 2

Santa Cruz, CA 95064

and NBER

jmrtwo@ucsc.edu 
Computers are an important part of modern education. In the United States, schools spend more than $\$ 5$ billion per year on computers and information technology (MDR 2004), while the federal government spends another $\$ 2$ billion per year on the E-rate program, which provides discounts to low-income schools and libraries (Universal Services Administration Company 2010). A large share of these expenditures goes towards in-school computing, and consequently access to computers in school is ubiquitous. ${ }^{1}$ In contrast, many children do not have access to a computer at home: nearly 9 million children ages 10-17 in the United States (27 percent) do not have computers with Internet connections at home (NTIA 2011). Partly to address these disparities and to further reduce computer-to-student ratios in the classroom, a growing number of schools are implementing costly one-to-one laptop programs (Silvernail et al. 2011; Texas Center for Educational Research 2009; Lowther 2007). ${ }^{2}$ These programs are extremely expensive -- for example, equipping each of the 55.5 million public school students in the United States with a laptop would cost tens of billions of dollars even if these laptops were replaced only every three years.

How important is this disparity in access to home computing to the educational achievement of schoolchildren, especially given the pervasiveness of computers in the U.S. classroom? The potential impact depends on why households do not have computers in the first place. If households are rational and face no other frictions, those households without computers have decided not to buy a computer because the returns are relatively low. Although home computers are useful for completing school assignments through word processing, research, spreadsheets and other educational uses, they also provide a distraction caused by game, social networking and other entertainment use. ${ }^{3}$ However, it is also possible that various constraints prevent households from investing in home computers, even if the returns are high. For example,

\footnotetext{
${ }^{1}$ There are an estimated 15.5 million instructional computers in U.S. public schools, representing one instructional computer for every three schoolchildren. Nearly every instructional classroom in these schools has a computer, averaging 189 computers per school (U.S. Department of Education 2011). ${ }^{2}$ Extensive efforts to provide laptops to schoolchildren also exist in many developing countries. For example, the One Laptop per Child program has provided more than 2 million computers to schools in Uruguay, Peru, Argentina, Mexico and Rwanda, and new projects in Gaza, Afghanistan, Haiti, Ethiopia and Mongolia. See http://one.laptop.org/about/countries.

${ }^{3}$ Surveys of home computer use among schoolchildren indicate high levels of use for both schoolwork and entertainment (see U.S. Department of Commerce 2004; Lenhart et al. 2008; Lenhart 2009; Pew Internet Project 2008a, 2008b; U.S. Department of Education 2011; Kaiser Family Foundation 2010 for example). Theoretically, there is also no clear prediction of whether the net effects are positive or negative (see Beltran, Das and Fairlie 2010 for example).
} 
parents may simply be unaware of the returns to computer use, or they may face credit constraints. There is reason to suspect that these constraints might be important, given that households without computers tend to be substantially poorer and less educated than other households (U.S. Department of Commerce 2011). Thus, the effect of computers for such families is an open and important question.

Only a few studies have examined this question, and there is no consensus in this literature on even whether the effects of home computers are positive or negative. A few studies find large positive effects of home computers on various educational outcomes such as grades, test scores and cognitive skills (Attewell and Battle 1999; Fiorini 2010; Schmitt and Wadsworth 2006; Fairlie 2005; Beltran, Das and Fairlie 2010; Malamud and Pop-Eleches 2011), and an almost equal number of studies find evidence of modestly-sized to large negative effects of home computers on educational outcomes (Fuchs and Woessmann 2004; Vigdor and Ladd 2010; Malamud and Pop-Eleches 2011). Thus, it remains an open question as to whether home computers are academically beneficial or harmful to schoolchildren. ${ }^{4}$

Empirically, the key challenge in the literature is isolating the causal effect of home computers from other unobserved differences across students and their families. Previous studies address concerns about possible omitted variable bias (mainly due to selection) by controlling for detailed student and family background characteristics, instrumenting for computer ownership, performing falsification tests, and/or estimating fixed effect models (for example, see Attewell and Battle 1999; Fiorini 2010; Schmitt and Wadsworth 2006; Fuchs and Woessmann 2004; Fairlie 2005; Vigdor and Ladd 2010; Beltran, Das and Fairlie 2010). More recently to address selection bias, Malamud and Pop-Eleches (2011) estimate a regression discontinuity design using a computer voucher program for low-income families in Romania. Their estimates indicate negative effects of having a home computer on grades, but positive effects on cognitive and

\footnotetext{
${ }^{4}$ A larger and more established literature examines the impacts of computers and computer-assisted software in schools (where use is regulated by teachers) and finds somewhat mixed results ranging from null to large positive impacts. See Kirkpatrick and Cuban (1998) and Noll, et al. (2000) for earlier reviews of the literature, and see Barrera-Osorio and Linden (2009) and Cristia, et al. (2012) for more recent evidence on computer impacts in schools, Goolsbee and Guryan (2006) and Machin, McNally and Silva (2007) for evidence on the effects of ICT expenditures and subsidies to schools, and Angrist and Lavy (2002), Banerjee, et al. (2007), Barrow, Markman and Rouse (2009) and Carrillo, Onofa and Ponce (2010) for evidence on computer-assisted software in schools. These results contrast with stronger evidence of positive effects for other school inputs such as teacher quality (e.g. Rivkin, Hanushek, and Kain 2005).
} 
computer skills. The only randomized experiment examining the impacts of home computers of which we are aware was conducted by one of the authors with a sample of 286 low-income community college students (Fairlie and London 2012). ${ }^{5}$ That study found evidence of small positive effects on educational outcomes for college students, but did not estimate impacts on schoolchildren, which may differ greatly. ${ }^{6}$

We provide evidence on the educational impacts of home computers by conducting a randomized control experiment with 1,123 students in grades 6-10 attending 15 schools across California. It represents the first field experiment involving the provision of free computers to schoolchildren for home use ever conducted, and the largest experiment involving the provision of free home computers to students at any level. All of the students participating in the study did not have computers at baseline. Half were randomly selected to receive free computers, while the other half served as the control group. Since the goal of the study was to evaluate the effects of home computers alone instead of a broader technology policy intervention, no training or other assistance was provided. At the end of the school year, we obtained administrative data from schools to test the effects of the computers on numerous educational outcomes. The reliance on school-provided administrative data available for almost all students for the main education outcomes essentially eliminates concerns over attrition bias and measurement error. We supplement this information with a detailed follow-up survey, which includes information on computer use and homework effort, in addition to other outcomes.

We find that even though the experiment had a large effect on computer ownership and total hours of computer use, there is no evidence of an effect on a host of educational outcomes,

\footnotetext{
${ }^{5}$ A few randomized control experiments have recently been conducted to examine the effectiveness of computer-assisted instruction in schools (e.g. Barrow, Markman and Rouse 2009, Mathematica 2009, Banerjee, et al. 2007, Barrera-Osorio and Linden 2009) and laptop use in schools (Cristia et al. 2012). Although the One Laptop per Child program in Peru (Cristia et al. 2012) and the Texas laptop program (evaluated with a quasi-experiment in Texas Center for Educational Research 2009) were initially intended to allow students to take computers home when needed in addition to using them in school, this did not happen in most cases. In Peru, some principals, and even parents, did not allow the computers to come home because of concerns that the laptops would not be replaced through the program if they were damaged or stolen. The result is that only 40 percent of students took the laptops home, and home use was substantially lower than in-school use. In Texas, there were similar concerns resulting in many schools not allowing computers to be taken home or restricting their home use. The main effect from these laptop programs is therefore to provide one computer for every student in the classroom, rather than to increase home access.

${ }^{6}$ From an analysis of matched CPS data, the study finds estimates of impacts of home computers on community college students that are nearly an order of magnitude larger than the experimental estimates raising concerns about potential biases in non-experimental estimates (Fairlie and London 2012).
} 
including grades, standardized test scores, credits earned, attendance, and disciplinary actions. We do not find effects at the mean, important cutoffs in the distribution (e.g. passing and proficiency), or quantiles in the distribution. Our estimates are precise enough to rule out even moderately-sized positive or negative effects. Evidence from our detailed follow-up survey supports these findings. We find no evidence that treatment students spent more or less time on homework, and we find that the computers had no effect on turning homework in on time, software use, computer knowledge, and other intermediate inputs in education. The pattern of time usage is also consistent with a negligible effect of the computers - while treatment students did report spending more time on computers for schoolwork, they also spent more time on games, social networking and other entertainment. Children also report relatively low hours spent doing homework overall which may have limited the potential for the computers to increase the productivity of their homework even if effective. Finally, we find no evidence of heterogeneous treatment effects by pre-treatment academic achievement, parental supervision, propensity for non-game use, or major demographic group. Overall, these results suggest that increasing access to home computers among students who do not already have access is unlikely to greatly improve educational outcomes, but is also unlikely to negatively affect outcomes. ${ }^{7}$

The remainder of the paper is organized as follows. In Section 2 we describe the computer experiment in detail and present a check of baseline balance between the treatment and control groups. Section 3 presents our main experimental results. Section 4 presents results for heterogeneous treatment effects. Section 5 concludes.

\section{Experimental Design}

\section{A. Sample}

The sample for this study includes students enrolled in grades 6-10 in 15 different middle and high schools in 5 school districts in the United States. Middle school students comprise the vast majority of the sample. ${ }^{8}$ We focus on this age group because younger students (i.e. elementary school students) would likely have less of a need to use computers for schoolwork

\footnotetext{
${ }^{7}$ The negative effects of home computers have gained a fair amount of attention recently in the press. See, for example, "Computers at Home: Educational Hope vs. Teenage Reality," NY Times, July 10, 2010 and "Wasting Time Is New Divide in Digital Era," NY Times, May 29, 2012.

${ }^{8}$ The distribution of grade levels is as follows: $9.5 \%$ grade $6,47.8 \%$ grade $7,39.9 \%$ grade 8 , and $2.8 \%$ grades 9 and 10 .
} 
and because middle school captures a critical time in the educational process for schoolchildren prior to, but influencing later, decisions about taking college prep courses and dropping out of school. The project took place over two years: two schools participated in 2008-9, twelve schools participated in 2009-10, and one school participated in both years. The 15 schools in the study span the Central Valley of California geographically. Overall, these schools are similar in size (749 students compared to 781 students), student to teacher ratio (20.4 to 22.6), and female to male student ratio (1.02 to 1.05) as California schools as a whole (U.S. Department of Education 2011). Our schools, however, are poorer ( $81 \%$ free or reduced price lunch compared with 57\%) and have a higher percentage of minority students (82\% to $73 \%$ ) than the California average. They also have lower average test scores than the California average (3.2 compared with 3.6 in English-Language Arts and 3.1 compared with 3.3 in Math), but the differences are not large (California Department of Education 2010). Although these differences may impact our ability to generalize the results, low-income, ethnically diverse schools such as these are the ones most likely to enroll schoolchildren without home computers and be targeted by policies to address inequalities in access to technology (e.g. E-rate program and IDAs).

To identify children who did not have home computers, we conducted an in-class survey at the beginning of the school year with all of the students in the 15 participating schools. The survey, which took only a few minutes to complete, asked basic questions about home computer ownership and usage. To encourage honest responses, it was not announced to students that the survey would be used to determine eligibility for a free home computer (even most teachers did not know the purpose of the survey). Responses to the in-class survey are tabulated in Appendix Table A1. In total, 7,337 students completed in-class surveys, with 24 percent reporting not having a computer at home. This rate of home computer ownership is roughly comparable to the national average: - estimates from the 2010 CPS indicate that $27 \%$ of children aged $10-17$ do not have a computer with Internet access at home (U.S. Department of Education 2011).

Any student who reported not having a home computer was eligible for the study. ${ }^{9}$ In discussing the logistics of the study with school officials, school principals expressed concern

\footnotetext{
${ }^{9}$ Because eligibility for the study is based on not having a computer at home, our estimates capture the impact of computers on the educational outcomes of schoolchildren whose parents do not buy them on their own and do not necessarily capture the impact of computers for existing computer owners.

Schoolchildren without home computers, however, are the population of interest in considering policies to expand access.
} 
about the fairness of giving computers to a subset of eligible children. For this reason, we decided to give out computers to all eligible students: treatment students received computers immediately, while control students had to wait until the end of the school year. Our main outcomes are all measured at the end of the school year, before the control students received their computers.

All eligible students were given an informational packet, baseline survey, and consent form to complete at home. To participate, children had to have their parents sign the consent form (which, in addition to participating in the study, released future grade, test score and administrative data) and return the completed survey to the school. Of the 1,636 students eligible for the study, we received 1,123 responses with valid consent forms and completed questionnaires (68.6\%). ${ }^{10}$

\section{B. Treatment}

We randomized treatment at the individual level, stratified by school. In total, of the 1,123 participants, 559 were randomly assigned to the treatment group. The computers were purchased from or donated by Computers for Classrooms, Inc., a Microsoft-certified computer refurbisher located in Chico, California. The computers were refurbished Pentium machines with 17" monitors, modems, ethernet cards, CD drives, flash drives, Microsoft Windows, and Microsoft Office (Word, Excel, PowerPoint, Outlook). The computer came with a 1 year warranty on hardware and software during which Computers for Classrooms offered to replace any computer not functioning properly. In total, the retail value of the machines was approximately $\$ 400-500$ a unit. Since the focus of the project was to estimate the impacts of home computers on educational outcomes and not to evaluate a more intensive technology policy intervention, no training or assistance was provided with the computers. ${ }^{11}$

\footnotetext{
${ }^{10}$ This percentage is lowered by two schools in which $35 \%$ or less of the children returned a survey (because of administrative problems at the school). However, there may certainly be cases in which students did not participate because they lost or did not bring home the flier advertising the study, their parents did not provide consent to be in the study, or they did not want a computer. Thus, participating students are probably likely to be more interested in receiving computers than non-participating students (which would also be the case in a real-world voucher or giveaway program). To deal with this, we focus on Intent-to-Treat effects in our main specifications. Note also that the results we present below are not sensitive to excluding the two schools with low participation rates.

${ }^{11}$ When the computers were handed out to students they were offered a partially subsidized rate for dialup Internet service from ChicoNet (\$30 for 6 months). They were also given some information about
} 
The computers were handed out by the schools to eligible students in the late fall of the school year (they could not be handed out earlier because it took some time to conduct the inschool surveys, obtain consent, and arrange the distribution). Because the computers were handed out in the second quarter of the school year we use first quarter grades as a measure of pre-treatment performance and third and fourth quarter grades as measures of post-treatment performance. Almost all of the students sampled for computers received them: we received reports of only 11 children who did not pick up their computers, and 7 of these had dropped out of their school by that time. After the distribution, neither the research team nor Computers for Classrooms had any contact with students during the school year. In addition, many of the outcomes were collected at least 6 months after the computers were given out (for example, endof-year standardized test scores and fourth quarter grades). Thus, it is very unlikely that student behavior would have changed for any reason other than the computers themselves (for instance, via Hawthorne effects).

\section{Data}

We use five main sources of data. First, the schools provided us with detailed administrative data on educational outcomes for all students covering the entire academic year. This includes grades in all courses taken, disciplinary information, and whether the student was still enrolled in school by the end of the year. Second, schools provided us with standardized test scores from the California Standardized Testing and Reporting (STAR) program. A major advantage of these two administrative datasets is that the outcomes are measured without any measurement error, and attrition is virtually non-existent. Third, the schools also provided pretreatment administrative data, such as quarter 1 grades, scores on the prior year's California STAR tests, and several student and household demographic variables obtained on school registration forms. Fourth, we administered a baseline survey which was required to participate in the project (as that was where consent was obtained). That survey includes additional information on student and household characteristics, and several measures of parental supervision and propensity for game use. Finally, we administered a follow-up survey at the end of the school year, which included detailed questions about computer ownership, usage, and

current Internet options available through AT\&T (these options were available to everyone, not just participants). 
knowledge, homework time, and other related outcomes. We use this survey to calculate a "first stage” of the program on computer usage, and to examine intermediate inputs which are not captured in the administrative data.

Appendix Table A2 reports information on attrition from the various datasets for the 1,123 students initially enrolled in the study. Panel A focuses on administrative outcomes. For the grade and other school outcome data 99\% of students appear in the various administrative datasets that the schools provided. Panel B focuses on the STAR test, which is also provided in administrative data from the schools and is conducted in the late spring. For those students still enrolled at the end of the year (and thus could have taken the test), we have test scores for 96\% of students (which may be driven by absent students during the day of the test). Another $9 \%$ of the sample had left school by the time of the test, so our data includes $87 \%$ of the full sample. Panel B also reports attrition information for the follow-up survey. We have follow-up surveys for $76 \%$ of all students and $84 \%$ of all students enrolled at the end of the school year.

Reassuringly, none of the response rates differ between the treatment and control groups.

\section{Summary Statistics and Randomization Verification}

Table 1 reports summary statistics for the treatment and control groups and provides a balance check. In the table, Columns 1 and 2 report the means for the treatment and control groups, respectively, while Column 3 reports the p-value for a t-test of equality. Panel A reports demographic information from the school-provided administrative data. The average age of study participants is 12.9 years. The sample has high concentrations of minority and non-primary English language students: 55\% of students are Latino, and 43\% primarily speak English at home. Most students, however, were born in the United States: the immigrant share is 19\%. The average education level of the highest educated parent is 12.8 years.

Panel B reports information on grades in the quarter before the computers were disbursed (the first quarter of the school year) and previous year California STAR test scores. The average student had a baseline GPA of roughly 2.5 in all subjects and 2.3 in academic subjects (which we define as Math, English, Social Studies, Science, and Computers). The average student received a score of roughly 2.9 (out of 5) on both the English-Language Arts and Math sections of the STAR test. Reassuringly, none of these means for baseline academic performance differ between the treatment and control groups. 
Finally, Panel C reports information from the baseline survey. Ninety percent of children live with their mothers, but only 58\% live with their fathers. Students report that $47 \%$ of mothers and $72 \%$ of fathers are employed (conditional on living with the student). The average student reports spending about 3.7 hours a week on the computer, split about evenly between school and outside of school. We also collected several measures of parental involvement and supervision, to examine whether treatment impacts vary by these characteristics. Most students report that their parents have rules for how much TV they watch, that they have a curfew, and that they usually eat dinner with their parents.

Overall, we find very little difference between the treatment and control groups. The only variable with a difference that is statistically significant is that treatment children are more likely to have rules on how much TV they watch (although the difference of 0.05 is small relative to the base of 0.79). It is likely that this one difference is caused by random chance - nevertheless, we control for a large number of covariates in all of the regressions which follow.

\section{Main Results}

\section{A. Computer Ownership and Usage}

The experiment has a very large first-stage impact in terms of increasing computer ownership and hours of computer use. Table 2, Panel A reports treatment effects on computer ownership rates and total hours of computer use from the follow-up survey conducted at the end of the school year. ${ }^{12}$ We find very large effects on computer ownership and usage. We find that $81 \%$ of the treatment group and $26 \%$ of the control group report having a computer at follow-up. While this first-stage treatment effect of 55 percentage points is very large, if anything it is understated because only a very small fraction of the 559 students in the treatment group did not receive one (as noted above, we had reports of only 11 students who did not pick up their computer). In addition, any measurement error in computer ownership would understate the first stage. The treatment group is also 25 percentage points more likely to have Internet service at

\footnotetext{
12 The estimated treatment effects are from linear regressions that control for school, year, age, gender, ethnicity, grade, parental education, whether the student's primary language is English, whether the student is an immigrant, whether the parents live with the student, whether parents have rules for how much TV the student watches, and whether the parents have a job. Some of these variables are missing for some students. To avoid dropping these observations, we also include a dummy variable equal to 1 if the variable is missing for a student and code the original variable as a 0 (so that the coefficients are identified from those with non-missing values). Estimates of treatment effects are similar without controls.
} 
home than the control group (42\% of treatment students have Internet service, compared to $17 \%$ of control students).

We also have some estimates of total time use. We do not want to overemphasize these specific estimates of hours use, however, because of potential measurement error common in self-reported time use estimates. With that caveat in mind, we find large first-stage results on reported computer usage. The treatment group reports using a computer 2.5 hours more per week than the control group, which represents a substantial gain over the control group average of 4.2 hours per week. ${ }^{13}$ Reassuringly, this increase in total hours of computer use comes from home computer use. The similarity between the point estimate on total computer time and the point estimate on home computer time suggests that home use does not crowd out computer use at school or other locations.

Panel B shows how children use the computers. The computers were used for both educational and non-educational purposes. Children spend an additional 0.8 hours on schoolwork, 0.8 hours per week on games, and 0.6 hours on social networking. ${ }^{14}$ All of these increases are large relative to the control group means of 1.9, 0.8 and 0.6, respectively. Though we do not want to overemphasize the specific point estimates given possible underreporting of time use, the finding of home computer use for both schoolwork and entertainment purposes among schoolchildren is common to numerous national surveys of computer use (see Pew Internet Project 2008a, 2008b, U.S. Department of Education 2011, Kaiser Family Foundation 2010 for example).

\section{B. Grades}

Table 3 reports estimates of treatment effects on third and fourth quarter grades. ${ }^{15}$ These regressions are all at the course level, with standard errors clustered by student and with controls for the subject and quarter. In all specifications, we pool the quarter 3 and 4 grades together. We

\footnotetext{
${ }^{13}$ The 4.2 hours that control students spend on computers is spent mostly at school and in other locations (i.e. libraries, or a friend or relative's house). But, we do not find evidence of more hours of computer use by the control group at other locations which include a friend's house suggesting that these students did not indirectly benefit from using the computers at the homes of the treatment students.

${ }^{14}$ We also find larger medians and distributions that are to the right for the treatment group for these measures of schoolwork and game/networking use.

${ }^{15}$ The schools participating in our study provide quarterly grades instead of semester grades.
} 
find similar results when we estimate separate regressions for quarter 3 and quarter $4 .{ }^{16}$ We also include the same set of baseline controls as in Table 2. To further control for heterogeneity and improve precision, we control for pre-treatment GPA (in quarter 1). ${ }^{17}$ In Panel A, Columns 1-2 we regress a numeric equivalent of course letter grades on treatment. ${ }^{18}$ Column 1 includes courses taken in all subjects, while Column 2 restricts the sample to courses taken in "academic" subjects (which we define as Math, English/Reading, Social Studies, Science, and Computers). ${ }^{19}$ The Intent-to-Treat estimates of treatment effects are very close to zero, and precisely estimated. ${ }^{20}$ The standard errors on these estimates are only 0.04 for both specifications; thus, each side of the 95 percent confidence interval is only 0.08 GPA points, which is equivalent to roughly one-fourth of the effect of a “+” or “_“ grade modifier (i.e. the difference between a B and a $\mathrm{B}+$ ). The $95 \%$ confidence interval is therefore very precise (it is just $[-0.10,0.06]$ for all subjects, and [-0.05, 0.11] for academic subjects). We can thus rule out even modestly sized (positive or negative) effects of computers on grades.

In Columns 3-4, we supplement the overall grade estimate by focusing on the effects of home computers on the pass/fail part of the grade distribution. In all of our schools, a grade of Dor higher is considering passing and provides credit towards moving to the next grade level and graduation. Again, we find a small, very precisely estimated treatment effect. For both specifications we find a treatment effect estimate of 0.00 and a standard error of 0.01 for the pass rate.

\footnotetext{
${ }^{16}$ It is therefore not the case that our finding of a negligible effect of computers on grades is due to an adjustment period in which students learn to use the computers at the expense of schoolwork, and then later benefit from that investment.

${ }^{17}$ Estimates are similar without controlling for pre-treatment GPA or any of the individual controls. They are also similar if we use GPA as the dependent variable instead of individual course grades.

${ }^{18}$ We code $\mathrm{A}$ as $4, \mathrm{~B}$ as $3, \mathrm{C}$ as $2, \mathrm{D}$ as 1 , and $\mathrm{F}$ as 0 , and we assign 0.33 points for a +/- modifier.

${ }^{19} \mathrm{~A}$ few students take computer classes which are included here, but we do not include recreational courses such as Art and P.E.

${ }^{20}$ LATE (or IV) estimates would be about twice as large (since the difference in computer usage is 55 percentage points). We do not report these estimates, however, because we cannot technically scale up the coefficients with the IV estimator because of differential timing of purchasing computers over the school year by the control group (two thirds of the control group with a home computer at follow-up obtained this computer after the fall). The finding that 82 percent of the treatment group reports having a computer at the end of the school year also creates difficulty in scaling up the ITT estimates because we know that essentially all treatment students picked up their computers and that many of the treatment group reporting not having a computer at follow-up indeed had a computer at home (based on subsequent conversations with the students by principals). For these reasons we focus on the ITT estimates.
} 
In Panel B of Table 3, we examine course grades separately by subject area (controlling for the quarter 1 grade in that subject). ${ }^{21}$ In the Panel, we report course grade results for each subject separately to test whether the overall null effect is hiding offsetting effects in specific subjects. ${ }^{22}$ As before, we present results for grades in the first set of columns (Columns 1-4) and for passing the course in the second set of columns (Columns 5-8). We find small, statistically insignificant coefficients in all specifications, suggesting that treatment students did no better or worse than control students in any subject.

The finding of a zero average treatment effect also does not appear to be due to offsetting effects at the bottom and top of the grade distribution. Figure 1 displays estimates and $95 \%$ confidence intervals from quantile regressions to test for differential treatment effects across the post-treatment achievement distribution that could be hidden by focusing only on mean impacts (e.g. Bitler, et al. 2004). Estimates of quantile treatment effects are indistinguishable from zero throughout the distribution. ${ }^{23}$

Overall, the results in this section suggest that computers do not have an impact on grades for students at any point in the distribution. The estimates are robust to focusing on the pass/fail cutoff and quantile treatment effects. We now turn to examining impacts on test scores.

\section{Test Scores}

Our second main outcome is performance on the California Standardized Testing and Reporting (STAR) Program tests. As part of the STAR Program, all California students are required to take standardized tests for English-Language Arts and math each spring. While grades may be the most likely outcome to change because home computers might help or distract students from turning in homework assignments, test scores focus on the impacts on the amount of information children learned during the school year.

Table 4 reports estimates of treatment effects for STAR scores in English (Columns 1 and 2) and math (Columns 3 and 4). The dependent variable in Panel A is the score on the test (standardized within the control group, so that the dependent variable has mean 0 and standard

\footnotetext{
${ }^{21}$ We find no evidence of treatment/control differences in course subjects taken which is consistent with students following their standard curriculum for the school year.

${ }^{22}$ We cannot estimate separate specifications for Computer classes because there are so few students who take Computer classes.

${ }^{23}$ The estimates displayed in Figure 3 do not control for baseline covariates. Estimates that control for baseline covariates look similar.
} 
deviation 1 among control students), while in Panel B it is a dummy for whether the student is proficient or advanced (getting a 4 or 5 out of 5 on the test). Proficiency and advanced scores meet state standards and are important for schools to satisfy Adequate Yearly Progress (AYP) as part of the No Child Left Behind Act. In Columns 1 and 3 of both panels, we include the same controls as in the previous tables. In Columns 2 and 4 we also include STAR scores from the previous school year.

From Panel A, we find no evidence of an effect of home computers on test scores (with or without controlling for the previous year's test score). The point estimates are small and very close to zero in all specifications. Focusing on whether students meet proficiency standards in Panel B, we also find no evidence of home computer effects on STAR scores. The treatment effect point estimates are zero or very close to zero. Confidence intervals around these point estimates are tight. For English, the 95\% confidence interval is -0.15 to 0.05 standard deviations for the standardized score and -0.04 to 0.04 for the proficiency indicator. For Math, the 95\% confidence intervals are -0.16 to 0.04 standard deviations and -0.08 to 0.04 for the standardized score and proficiency indicator, respectively.

Figure 2 examines the distribution of test scores. Since the STAR scores are lumped into only 5 bins, we cannot estimate quantile treatment effects. Figure 2 therefore instead plots inverse cumulative distribution functions (CDFs) for both STAR scores, for the treatment and control groups. The CDFs have substantial overlap between the treatment and control groups for both test scores. We find very small ranges over which the distributions do not perfectly overlap suggesting that there are essentially no differential treatment effects at any part of the test score distribution. Thus, mean impact estimates do not appear to be hiding offsetting effects at different parts of the distribution.

\section{Other Educational Outcomes}

The schools participating in the study provided us with a rich set of additional educational outcomes. From administrative data we examine total credits earned by the end of the third and fourth quarters, the number of unexcused absences, the number of tardies, and whether the student was still enrolled in the school at the end of the year. These measures of educational outcomes complement the results for grades and test scores. 
Table 5 reports estimates of treatment effects. Students receiving home computers do not differ from the control group in the total number of credits earned by the end of the $3^{\text {rd }}$ or $4^{\text {th }}$ quarters of the school year. Thus, the home computers are not changing the likelihood that children will be able to move on to the next grade level. Receiving a home computer also does not have an effect on the number of unexcused absences or tardies during the school year, suggesting that it does not alter their motivations about school. Finally, treatment students are no more likely to be enrolled in school at the end of the year than control students. Taken together, these results on additional educational outcomes support the conclusions drawn from the grade and test score results of no effects of home computers. ${ }^{24}$

\section{E. Intermediate Inputs and Outcomes from the Follow-up Survey}

The follow-up survey provides information on several less-commonly measured intermediate educational inputs and outcomes such as homework effort and time, receiving help on assignments, software use, and computer knowledge. We examine the impact of home computers on these intermediate inputs in Table 6. In Panel A, we find no evidence that treatment students spent more time on the last essay or project they had for school. The treatment group is also no more likely to turn their homework in on time. This latter result is interesting in that reported homework effort is quite low such that there appears to be scope for improvement only $47 \%$ of control students reported that they "always" hand assignments in on time. We also find no difference between treatment and control students in the likelihood that they receive help on school assignments from other students, friends, or teachers by email or networking. Finally, we examine whether having a home computer crowds out total time spent doing homework (Column 6). High levels of use of home computers for games, social networking, and other forms of entertainment have raised concerns about the displacement of homework time. ${ }^{25}$

\footnotetext{
${ }^{24}$ We also summarize the results for educational outcomes by aggregating the separate measures into a standardized z-score as in Kling, Liebman, and Katz (2007). A regression of a z-score of the main 3 academic outcomes (grades and the 2 test scores) including the same set of controls as we have used throughout yields a coefficient of -0.05 standard deviations with a standard error of 0.05 . Also including the five main administrative outcomes in Table 5 yields a coefficient of -0.02 standard deviations with a standard error of 0.03 .

${ }^{25}$ These concerns are similar to those over television (Zavodny 2006). There is consistent evidence across many different surveys showing high levels of game, social networking, and other non-educational uses of computers by children (see U.S. Department of Commerce 2004; Lenhart et al. 2008; Lenhart 2009;
} 
However, we find no evidence that the treatment group reports lower hours of homework time than the control group.

We also asked students what they use computers for and what they know how to do with computers. ${ }^{26}$ In Panel B, we include answers to questions about what types of software students use (including word processing, researching projects or reports, using a spreadsheet, and educational software). Even though baseline usage levels are low for some types of software use, we find no major differences between the treatment and control groups in this dimension. In Panel C, we asked students whether they knew how to use a computer for various tasks. Again, baseline knowledge levels are low - for example, 49\% of students report knowing how to download a file from the Internet, $46 \%$ report knowing how to email a file, and $62 \%$ report knowing how to save a file to the hard drive. Despite this, we find no treatment difference in any of these measures. These results for software use and knowledge and the results for other intermediate educational inputs are consistent with the lack of positive or negative effects for the more ultimate academic outcomes examined above.

\section{Treatment Heterogeneity}

The results presented thus far provide consistent evidence against the hypothesis that home computers exert a positive or negative effect on academic outcomes at the average and at notable cutoffs in the achievement distribution such as the pass rate and meeting proficiency standards. In addition, the results from the quantile treatment effect regressions do not provide evidence that home computers shift the achievement distribution at any point in the distribution in a discernible way. In this section, we explore whether there might be heterogeneity in treatment effects by various baseline characteristics. We focus specifically on pre-treatment ability, parental supervision, propensity for game/social networking use, and basic demographic characteristics. Focusing on these particular measures is partly motivated by findings from the previous literature, and all of these measures were pre-identified at the start of the project (which is why they were asked at baseline).

Pew Internet Project 2008a, 2008b; U.S. Department of Education 2011; Kaiser Family Foundation 2010 for example).

${ }^{26}$ These questions were loosely based on the CPS Computer and Internet Supplement, the Microsoft Digital Literacy Test, and Hargittai (2005). 
We start by examining heterogeneity by baseline academic achievement. Figure 3 examines treatment effects focusing on potential differences across the pre-treatment grade distribution. The graph presents coefficients from the following regression:

(1) $Y_{i}=\beta_{p c} * D_{i p} * C_{i}+\beta_{p t} * D_{i p} * T_{i}+\delta X_{i}+\varepsilon_{i}$

In the regression, $D_{i p}$ is an indicator for whether individual $i$ is in the $p$ th percentile of the pretreatment GPA distribution. Percentiles are calculated within each school and are restricted to 20 different percentile categories. $C_{i}$ is an indicator for the control group, and $T_{i}$ is an indicator for the treatment group. Thus, $\beta_{p c}$ and $\beta_{p t}$ are estimates of the relationship between pre- and posttreatment performance in the control and treatment groups, respectively, and the difference, $\beta_{p t}-\beta_{p c}$ provides an estimate of the treatment effect at the $p$ th percentile. $X_{i}$ is a minimal set of controls, including only subject and quarter indicators (so that the coefficients represent the unconditional relationship between pre- and post-performance for the treatment and control groups). Standard errors are clustered at the individual level, and the $95 \%$ confidence interval of the difference between the treatment and control groups is plotted.

The estimates displayed in the figure indicate that treatment effects are indistinguishable from zero at almost all points of the pre-treatment grade distribution. ${ }^{27}$ Similarly, Figure 4 examines the effects of home computers on STAR scores by prior achievement levels. Again, there is no discernible effect at almost any point in the pre-treatment STAR distribution. These figures suggest minimal effects of computers across the pre-treatment ability distribution and rule out the possibility that the null estimates of average treatment effects are due to offsetting positive and negative treatment effects at different parts of the pre-treatment achievement distribution.

The null effects found above might instead be due to positive effects of home computers on educational outcomes simply offsetting the negative effects from non-educational uses. Computers might be particularly harmful to students who have a high propensity to use them for non-educational purposes (either because their parents do not monitor them closely or because the children are intrinsically more inclined to use them for entertainment).

To explore this question, we first examine whether there is heterogeneity in treatment effects based on parental supervision. In their study of Romanian schoolchildren, Malamud and

\footnotetext{
${ }^{27}$ Appendix Table A3 shows these results in a regression framework as well as treatment interactions with pre-treatment levels.
} 
Pop-Eleches (2011) find evidence that parental supervision through rules on homework activities attenuates some of the negative effects of home computers on grades that they find in the main specifications. ${ }^{28}$ In designing the baseline survey we asked questions about having rules over how much TV they can watch and whether they have a curfew to measure parental supervision. ${ }^{29}$ Table 7 reports estimates of heterogeneous treatment effects for these two variables. We find that treatment students with curfews increase game use less than other students. However, this difference is evidently too small to have any meaningful impact on outcomes - we do not find a relative increase in time devoted to doing homework, grades, or test scores. We also find no evidence suggesting that children with rules for watching TV benefited more or less from home computers.

Computers might be harmful to students who have a high propensity to use them for noneducational purposes. Although this is difficult to measure, we included questions on video game use (e.g. Wii, Xbox) and having a social networking page on the baseline survey. These measures are clearly not perfect because families that have a video game console or children who have a social networking page, but do not have a computer at home, might differ along many dimensions. But, both baseline measures are exogenous to treatment and provide some suggestive evidence on the question. Table 8 reports estimates of heterogeneous treatment effects by these two measures. The estimates generally show no differential effects of home computers on outcomes by whether students have a propensity to use computers for non-educational purposes. The one somewhat surprising result is that we find a negative level effect of having a social networking page, but a positive interaction effect in the grade regression. One possible interpretation of this result is that playing on a computer at home is less of a distraction than going to a friend's house to use a computer, though since this is the only significant result it may well be due to sampling variation. Otherwise, we find no heterogeneity along these dimensions. ${ }^{30}$

\footnotetext{
${ }^{28}$ Malamud and Pop-Eleches (2011) also examine interactions with parental rules regarding computer use, but do not find evidence that they mitigate the negative effects of home computers on school grades. One concern that they note in the paper is that information on parental rules for homework activities and computer use are gleaned from a survey after the children received computers - making these rules potentially endogenous.

${ }^{29}$ We also collected information on whether the child usually eats dinner with his/her parents. We find similar results as those for TV rules and having a curfew.

${ }^{30}$ Another reason that use of computers for entertainment might not affect academic outcomes is that very few students report substantial amounts of game and social networking use on the computer on the follow-up survey. Less than 6 percent of the treatment group reports using their home computers for
} 
We also examine how impacts vary with a few standard demographic background characteristics - gender, race, and grade in school. ${ }^{31}$ Appendix Table A4 reports estimates. We find no evidence of differential treatment effects. Although we do not find evidence of heterogeneity in impacts across these groups for the sample of children that do not have computers in the first place, it is important to note that we cannot necessarily infer that there is no heterogeneity in computer impacts across demographic groups for the broader population of schoolchildren. One issue that is especially salient for the comparison by minority status is that we are likely sampling from a different part of the distribution of overall minority students than non-minority students when we focus on non-computer owners (because of substantially lower rates of ownership among minorities even conditioning on income). But, these results do tell us whether there are differential benefits from home computers among schoolchildren that do not currently own computers, which is clearly relevant for policies to expand access to home computers. $^{32}$

\section{Conclusion}

Even today, roughly one out of every four children in the United States does not have a computer with Internet access at home (NTIA 2011). While this gap in access to home computers seems troubling, there is no theoretical or empirical consensus on whether the home computer is a valuable input in the educational production function and whether these disparities limit academic achievement. Prior studies show both large positive and negative impacts. We provide direct evidence on this question by performing an experiment in which 1,123 schoolchildren grades 6-10 across 15 different schools and 5 school districts in California were

\footnotetext{
games and social networking 10 or more hours per week. Another interesting finding from examining the joint distribution of schoolwork use and game/networking use is that most students did both, instead of there being a clear distinction between educational and game/social networking users.

${ }^{31}$ Previous survey evidence indicates that on average boys and girls use computers differently. Boys tend to use computers more for video games while girls tend to use them more for social networking (Pew Internet Project 2008a, 200b, U.S. Department of Education 2011, Kaiser Family Foundation 2010). Treatment effects may differ by race because of varying rates of access to personal computers at alternative locations such as at friends' and relatives' houses, and libraries, and social interactions with other computer users (Fairlie 2004; Goldfarb and Prince 2008; Ono and Zavodny 2007; NTIA 2011). Effects might also differ by grade because of curricular differences.

${ }^{32}$ We also test for social interactions in usage. To do this, we interact treatment with the percent of students with home computers in each school (based on results of our in-class survey reported in Appendix Table A1). We find no evidence of social interactions, which may be due to only having variation across schools and not students for this variable.
} 
randomly given computers to use at home. By only allowing children without computers to participate, placing no restrictions on what they could do with the computers, and obtaining administrative data with virtually no attrition and measurement error, the experiment was designed to improve the likelihood of detecting effects, either positive or negative.

Although the experiment substantially increased computer ownership and usage without causing substitution away from use at school or other locations outside the home, we find no evidence that home computers had an effect (either positive or negative) on any educational outcome, including grades, standardized test scores, or a host of other outcomes. Our estimates are precise enough to rule out even modestly-sized positive or negative impacts. We do not find effects at notable points in the distribution such as pass rates and meeting proficiency standards, throughout the distribution of post-treatment outcomes, throughout the distribution of pretreatment achievement, or for subgroups pre-identified as potentially more likely to benefit.

These findings are consistent with a detailed analysis of time use on the computer and "intermediate" inputs in education. We find that home computers increase total use of computers for schoolwork, but also increase total use of computers for games, social networking and other entertainment, which might offset each other. We also find no evidence of positive effects on additional inputs such as turning assignments in on time, time spent on essays, getting help on assignments, software use, and computer knowledge. On the other hand, we also find no evidence of a displacement of homework time. Game and social networking use might not have been extensive enough, within reasonable levels set by parents or interest by children, to negatively affect homework time, grades and test scores. The potential negative effects of computers for U.S. schoolchildren might also be much lower than the large negative effects on homework time and grades found for Romanian schoolchildren in Malamud and Pop-Eleches (2011), where most households do not have a computer at home, because there is less of a novelty of home computers for low-income schoolchildren in the United States for game use. Computers are also used much more extensively in U.S. schools which might exert more of a positive offsetting effect. Thus, for U.S. schoolchildren, and perhaps schoolchildren from other developed countries, concerns over the negative educational effects of computer use for games, social networking, and other forms of entertainment may be overstated.

An important caveat to our results is that there might be other effects of having a computer that are not captured in measurable academic outcomes. For example, computers may 
be useful for finding information about colleges, jobs, health and consumer products, and may be important for doing well later in higher education. It might also be useful for communicating with teachers and schools and parental supervision of student performance through student information system software. ${ }^{33} \mathrm{~A}$ better understanding of these potential benefits is important for future research.

Nevertheless, our results indicate that computer ownership alone is unlikely to have much of an impact on short-term schooling outcomes for low-income children. Existing and proposed interventions to reduce the remaining digital divide in the United States and other countries, such as large-scale voucher programs, tax breaks for educational purchases of computers, Individual Development Accounts (IDAs), and one-to-one laptop programs, need to be realistic about their potential to reduce the current achievement gap. ${ }^{34}$

\footnotetext{
${ }^{33}$ Student information system software that provides parents with nearly instantaneous information on their children's school performance, attendance and disciplinary actions is becoming increasingly popular in U.S. schools (e.g. School Loop, Zangle, ParentConnect, and Aspen). We find evidence from the follow-up survey of a positive effect of home computers on whether parents check assignments, grades and attendance online using these types of software.

${ }^{34}$ In the United States, in addition to one-to-one laptop programs, the American Recovery and Reinvestment Act of 2009 provides tax breaks for education-related purchases of computers, and there are many local IDAs in the United States that provide matching funds for education-related purchases of computers. England recently provided free computers to nearly 300,000 low-income families with children at a total cost of $£ 194$ million through the Home Access Programme. Another example is the Romanian Euro 200 program which provides vouchers to low-income families with children to purchase computers.
} 


\section{References}

Angrist, Joshua, and Victor Lavy. 2002. "New Evidence on Classroom Computers and Pupil Learning," Economic Journal 112(482): 735-765

Attewell, Paul, and Juan Battle. 1999. "Home Computers and School Performance," The Information Society 15: 1-10.

Banerjee, A., Cole, S., Duflo, E. and Linden, L (2007) "Remedying Education: Evidence from Two Randomized Experiments in India," Quarterly Journal of Economics 122(3): 1235-1264.

Barrow, Lisa, Lisa Markman, and Cecelia E. Rouse. 2009. "Technology's Edge: The Educational Benefits of Computer-Aided Instruction," American Economic Journal: Economic Policy 1(1): 52-74.

Barrera-Osorio, Felipe, and Leigh L. Linden. 2009. "The Use and Misuse of Computers in Education: Evidence from a Randomized Experiment in Colombia,” Policy Research Working Paper 4836, Impact Evaluation Series No. 29, The World Bank.

Beltran, Daniel O., Kuntal K. Das, and Robert W. Fairlie. 2010. "Home Computers and Educational Outcomes: Evidence from the NLSY97 and CPS," Economic Inquiry 48(3): 771792.

Bitler, Marianne, Jonah Gelbach and Hilary Hoynes. 2006. "What Mean Impacts Miss: Distributional Effects of Welfare Reform Experiments," American Economic Review 96(4): 988-1012.

California Department of Education. 2010. 2010 STAR Test Results: California STAR Program, http://star.cde.ca.gov/star2010/

Carrillo, Paul, Mercedes Onofa, and Juan Ponce. 2010. "Information Technology and Student Achievement: Evidence from a Randomized Experiment in Ecuador," Inter-American Development Bank Working Paper.

Cristia, Julian P., Pablo Ibarraran, Santiago Cueto, Ana Santiago, and Eugenio Severin. 2012. "Technology and Child Development: Evidence from the One Laptop per Child Program," InterAmerican Development Bank Working Paper No. IDB-WP-304.

Fairlie, Robert W. 2004. "Race and the Digital Divide," The B.E. Journal of Economic Analysis \& Policy 3(1), Contributions, Article 15: 1-38.

Fairlie, Robert W. 2005. "The Effects of Home Computers on School Enrollment," Economics of Education Review 24(5): 533-547. 
Fairlie, Robert W., and Rebecca A. London. 2012. "The Effects of Home Computers on Educational Outcomes: Evidence from a Field Experiment with Community College Students.” Economic Journal 122(561): 727-753.

Fiorini, M. 2010. “The Effect of Home Computer Use on Children’s Cognitive and NonCognitive Skills,” Economics of Education Review 29: 55-72.

Fuchs, Thomas, and Ludger Woessmann. 2004. "Computers and Student Learning: Bivariate and Multivariate Evidence on the Availability and Use of Computers at Home and at School." CESifo Working Paper No. 1321.

Goldfarb, Avi, and Jeffrey Prince. 2008. "Internet Adoption and Usage Patterns are Different: Implications for the Digital Divide." Information Economics and Policy 20(1), 2-15.

Goolsbee, Austan, and Jonathan Guryan. 2006. "The Impact of Internet Subsidies in Public Schools," The Review of Economics and Statistics 88(2): 336-347.

Hargittai, Eszter. 2005. "Survey Measures of Web-Oriented Digital Literacy," Social Science Computer Review 23(3): 371-379.

Kaiser Family Foundation. 2010. Generation $M^{2}$ : Media in the Lives of 8- to 18-Year Olds. Kaiser Family Foundation Study.

Kirkpatrick, H., and L. Cuban. 1998. "Computers Make Kids Smarter--Right?" Technos Quarterly for Education and Technology 7:2.

Kling, Jeffrey R., Jeffrey B. Liebman, and Lawrence F. Katz. 2007. "Experimental Analysis of Neighborhood Effects," Econometrica 75(1): 83-119.

Lenhart, Amanda. 2009. The Democratization of Online Social Networks: A look at the change in demographics of social network users over time, Pew Internet \& American Life Project, Presentation at AoIR 10.0, October 8, 2009.

Lenhart, Amanda, Joseph Kahne, Ellen Middaugh, Alexandra Rankin Macgill, Chris Evans, and Jessica Vitak. 2008. Teens, Video Games, and Civics: Teens' gaming experiences are diverse and include significant social interaction and civic engagement, Pew Internet and American Life Project.

Lowther, Deborah L., J. Daniel Strahl, Fethi A. Inan, and Jerry Bates. 2007. Freedom to Learn Program: Michigan 2005-2006 Evaluation Report, Center for Research in Educational Policy, The University of Memphis.

Machin, Stephen, Sandra McNally, and Olmo Silva. 2007. "New Technology in Schools: Is There a Payoff?" Economic Journal 117(522): 1145-1167. 
Malamud, Ofer, and Cristian Pop-Eleches. 2011. "Home Computer Use and the Development of Human Capital," Quarterly Journal of Economics 126: 987-1027.

Market Data Retrieval (MDR). 2004. Technology in Education. Market Data Retrieval: Shelton, Connecticut.

Mathematica. 2009. "Effectiveness of Reading and Mathematics Software Products: Findings from Two Student Cohorts," Report for U.S. Department of Education.

National Telecommunications and Information Administration. 2011. Current Population Survey (CPS) Internet Use 2010, http://www.ntia.doc.gov/data/CPS2010_Tables_.

Noll, Roger G. Noll, Dina Older-Aguilar, Gregory L. Rosston, and Richard R. Ross. 2000. "The Digital Divide: Definitions, Measurement, and Policy Issues," paper presented at Bridging the Digital Divide: California Public Affairs Forum, Stanford University.

Ono, Hiroshi, and Madeline Zavodny, 2007. "Digital Inequality: A Five Country Comparison Using Microdata,” Social Science Research 36: 1135-1155.

Pew Internet Project. 2008. Writing, Technology and Teens, Washington, D.C.: Pew Internet \& American Life Project.

Pew Internet Project. 2008. Teens, Video Games, and Civics, Washington, D.C.: Pew Internet \& American Life Project.

Rivkin, Steven G., Eric A. Hanushek, and John F. Kain. 2005. "Teachers, Schools, and Academic Achievement," Econometrica 73(2): 417-458.

Schmitt, John, and Jonathan Wadsworth. 2006. "Is There an Impact of Household Computer Ownership on Children's Educational Attainment in Britain?" Economics of Education Review, 25: 659-673.

Silvernail, David L., Caroline A. Pinkham, Sarah E. Wintle, Leanne C. Walker, and Courtney L. Bartlett. 2011. A Middle School One-to-One Laptop Program: The Maine Experience, Maine Education Policy Research Institute, University of Southern Maine.

Texas Center for Educational Research. 2009. Evaluation of the Texas Technology Immersion Pilot: Final Outcomes for a Four-Year Study (2004-05 to 2007-08).

U.S. Department of Education. 2011. Digest of Education Statistics 2010 (NCES 2008-022). National Center for Education Statistics, Institute of Education Sciences, U.S. Department of Education. Washington, DC.

U.S. Department of Education. 2011. “School Locator,” National Center for Educational Statistics, http://nces.ed.gov/ccd/schoolsearch/ 
Universal Services Administration Company. 2010. Annual Report

http://www.usac.org/about/tools/publications/annual-reports/2010/index.html.

Vigdor, Jacob L., and Helen F. Ladd. 2010. "Scaling the Digital Divide: Home Computer

Technology and Student Achievement," National Bureau of Economic Research Working Paper No. 16078.

Zavodny, Madeline. 2006. "Does Watching Television Rot Your Mind? Estimates of the Effect on Test Scores," Economics of Education Review 25: 565-573. 


\section{Figure 1: Quantile Treatment Effects (Grades)}

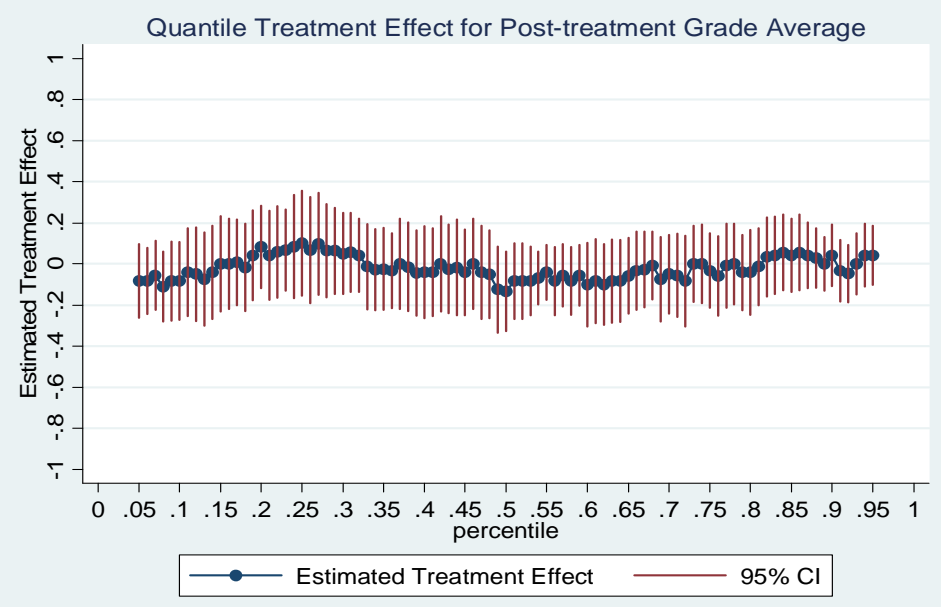

Notes: Dependent variable is the everage grade in post-treatment quarters (quarters 3 and 4) in academic subjects (Math, Science, Social Studies, English, and Computers). 
Figure 2. Inverse Post-Treatment CDFs for STAR scores

Panel A. English / Language Arts

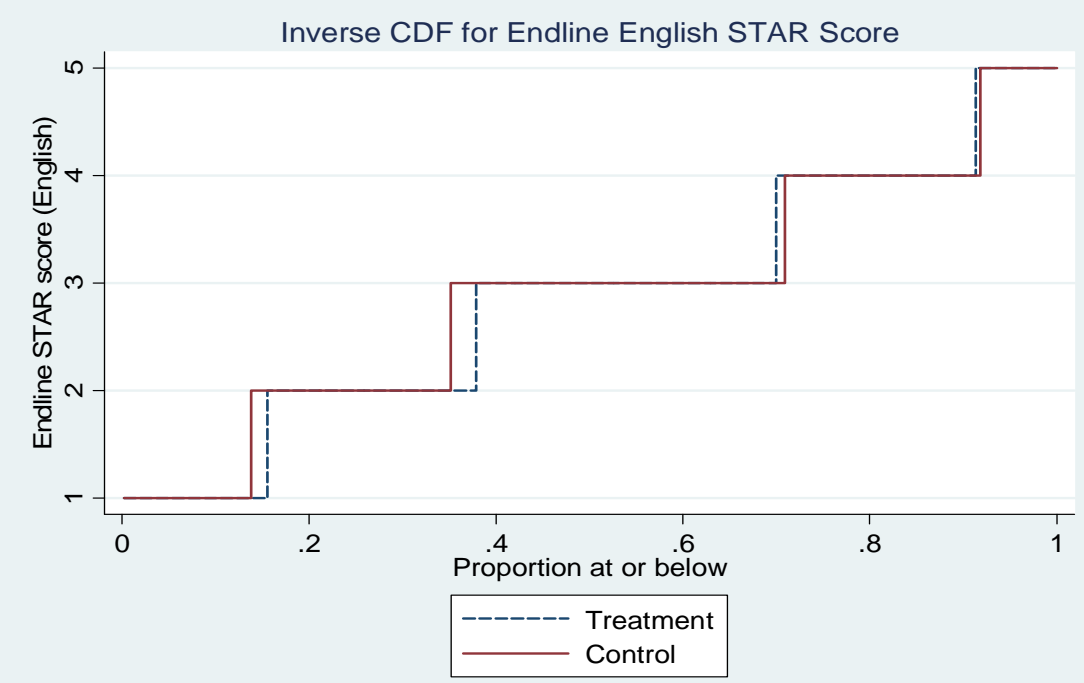

Panel B. Math

Inverse CDF for Endline Math STAR Score

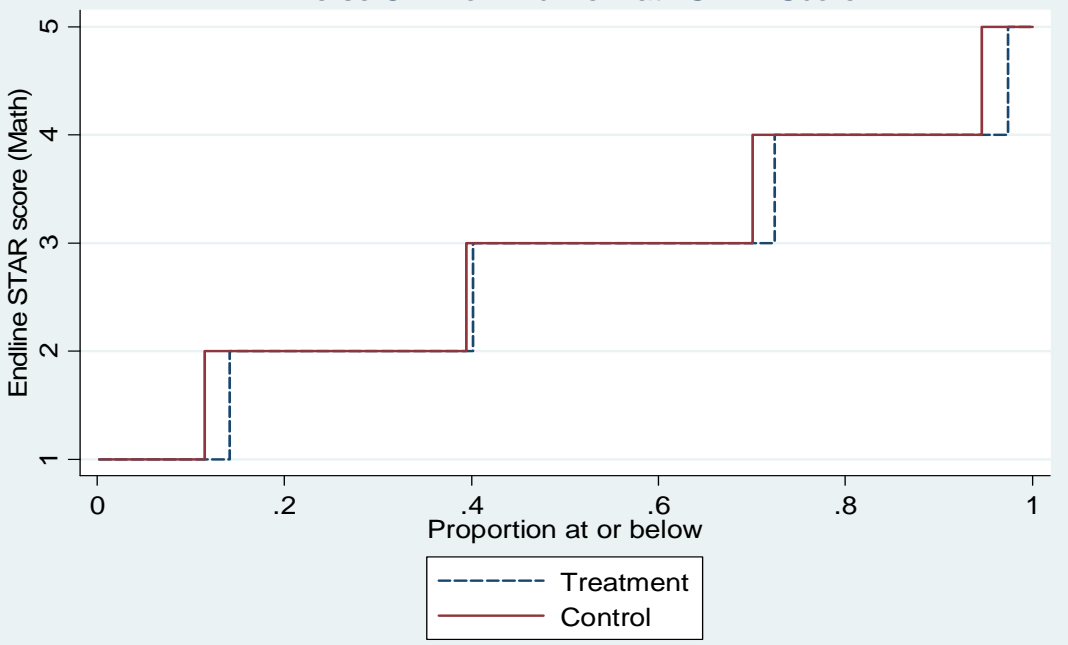

Notes: Figures depict inverse CDFs for endline STAR scores. 
Figure 3. Post-Treatment Grades by Pre-Treatment GPA Percentile (Quarter 1)

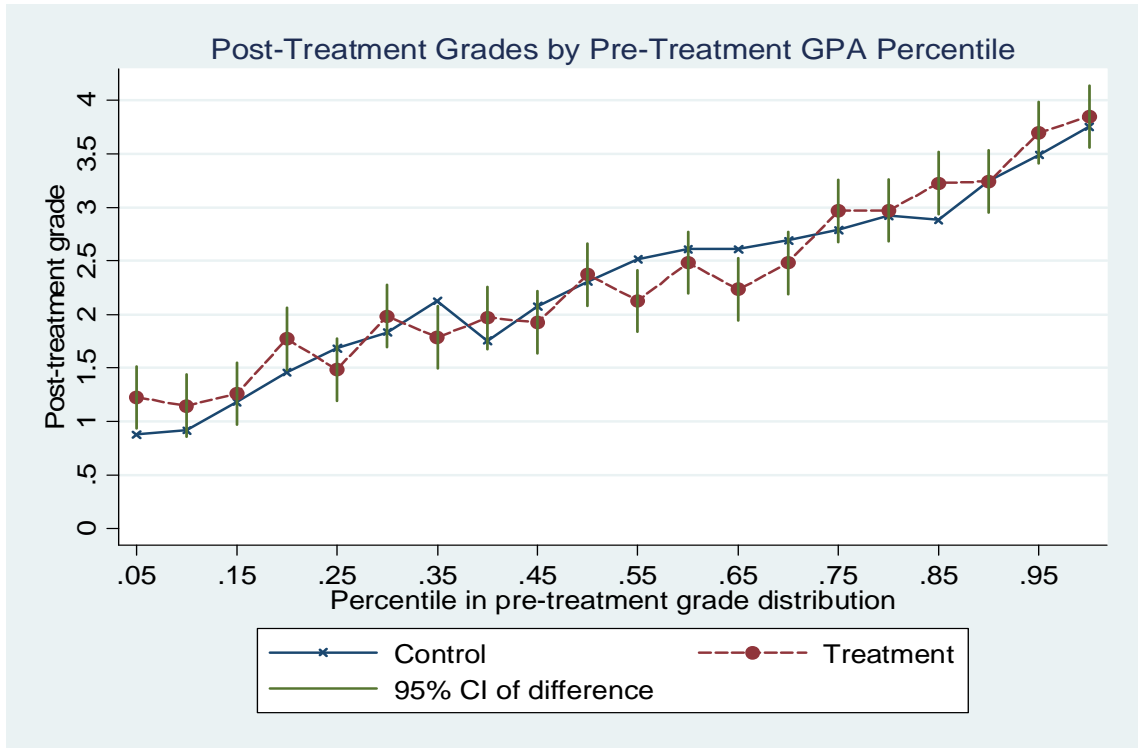

Notes: The graph shows estimated coefficients from a regression of post-treatment (quarters 3 and 4) grades on interactions between treatment and pre-treatment GPA percentile (in quarter 1, before the computers were given out).

The vertical line is a 95\% confidence interval for the difference between the treatment and control groups, at each percentile. The percentiles are calculated within each school. Regressions restricted to "academic subjects" (Math, Science, English, Social Studies, and Computers). Regressions control for the subject and whether the class was taken in quarter 3. There are 1,035 students and 7,202 observations in this regression. 
Figure 4. Post-Treatment STAR scores by Pre-Treatment Star Percentiles

Panel A. English / Language Arts

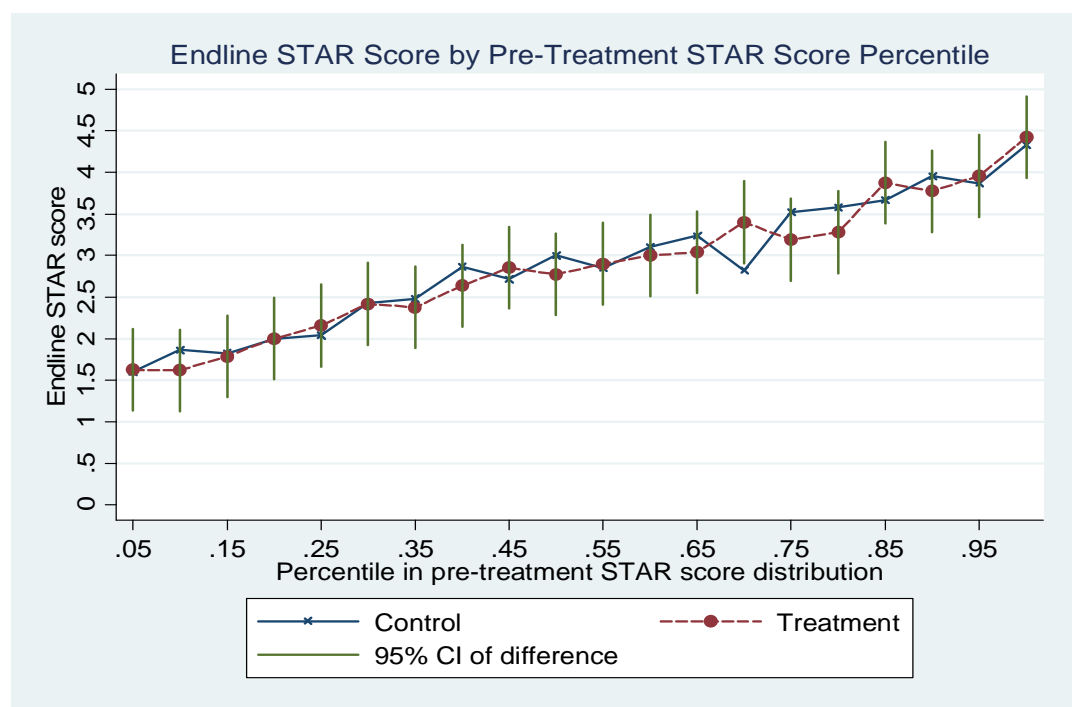

Panel B. Math

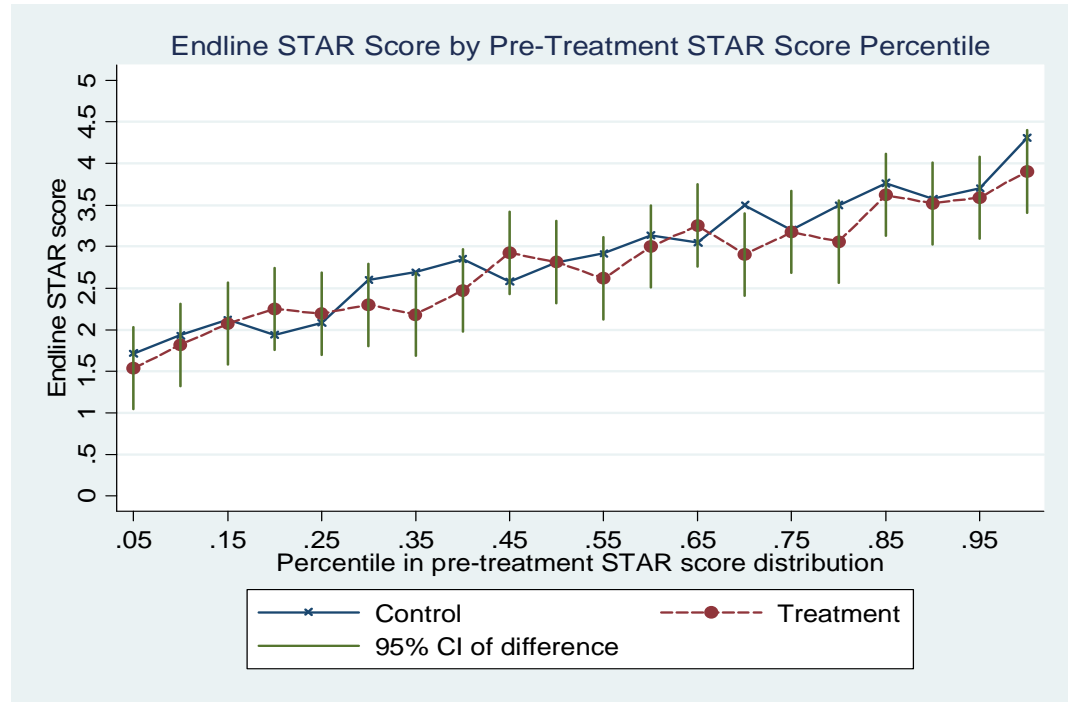

Notes: The graph shows estimated coefficients from a regression of endline STAR scores on interactions between treatment and pre-treatment STAR scores. The vertical line is a 95\% confidence interval for the difference between the treatment and control groups, at each percentile. The percentiles are calculated within each school. There are 865 students in Panel $A$ and 790 in Panel $B$. 
Table 1. Individual Level Summary Statistics and Balance Check

\begin{tabular}{|c|c|c|c|c|}
\hline & Control & Treatment & $\begin{array}{l}\text { Equality of } \\
\text { means } p \text {-val }\end{array}$ & Obs. \\
\hline \multicolumn{5}{|c|}{ Panel A. Administrative Data Provided by School } \\
\hline Age & $\begin{array}{l}12.91 \\
(0.87)\end{array}$ & $\begin{array}{l}12.90 \\
(0.84)\end{array}$ & 0.91 & 1107 \\
\hline Female & $\begin{array}{c}0.51 \\
(0.50)\end{array}$ & $\begin{array}{c}0.50 \\
(0.50)\end{array}$ & 0.66 & 1123 \\
\hline Ethnicity = African American & $\begin{array}{c}0.13 \\
(0.34)\end{array}$ & $\begin{array}{c}0.14 \\
(0.34)\end{array}$ & 0.86 & 1103 \\
\hline Ethnicity = Latino & $\begin{array}{c}0.56 \\
(0.50)\end{array}$ & $\begin{array}{c}0.55 \\
(0.50)\end{array}$ & 0.76 & 1103 \\
\hline Ethnicity = Asian & $\begin{array}{c}0.12 \\
(0.33)\end{array}$ & $\begin{array}{c}0.14 \\
(0.34)\end{array}$ & 0.42 & 1103 \\
\hline Ethnicity $=$ White $^{1}$ & $\begin{array}{c}0.16 \\
(0.36)\end{array}$ & $\begin{array}{c}0.14 \\
(0.35)\end{array}$ & 0.56 & 1103 \\
\hline Immigrant & $\begin{array}{c}0.21 \\
(0.41)\end{array}$ & $\begin{array}{c}0.18 \\
(0.38)\end{array}$ & 0.15 & 1092 \\
\hline Primary language is English & $\begin{array}{c}0.43 \\
(0.50)\end{array}$ & $\begin{array}{c}0.43 \\
(0.50)\end{array}$ & 0.97 & 1102 \\
\hline Parent's education ${ }^{2}$ & $\begin{array}{l}12.81 \\
(1.44)\end{array}$ & $\begin{array}{l}12.76 \\
(1.49)\end{array}$ & 0.64 & 729 \\
\hline Number of people living in household & $\begin{array}{c}4.98 \\
(2.43)\end{array}$ & $\begin{array}{c}5.02 \\
(2.55)\end{array}$ & 0.79 & 1103 \\
\hline \multicolumn{5}{|c|}{ Panel B. Pre-treatment grades and test scores } \\
\hline $\begin{array}{l}\text { Grade point average in all subjects } \\
\text { (in Quarter 1) }\end{array}$ & $\begin{array}{c}2.56 \\
(0.92)\end{array}$ & $\begin{array}{c}2.53 \\
(0.92)\end{array}$ & 0.54 & 1098 \\
\hline $\begin{array}{l}\text { Grade point average in academic subjects } \\
\text { (in Quarter } 1)^{3}\end{array}$ & $\begin{array}{c}2.35 \\
(1.05)\end{array}$ & $\begin{array}{c}2.29 \\
(1.05)\end{array}$ & 0.30 & 1098 \\
\hline $\begin{array}{l}\text { California STAR test in previous year } \\
\text { (English) }\end{array}$ & $\begin{array}{c}2.89 \\
(1.06)\end{array}$ & $\begin{array}{c}2.92 \\
(1.11)\end{array}$ & 0.76 & 929 \\
\hline $\begin{array}{l}\text { California STAR test in previous year } \\
\text { (Math) }\end{array}$ & $\begin{array}{c}2.91 \\
(1.10)\end{array}$ & $\begin{array}{c}2.92 \\
(1.12)\end{array}$ & 0.80 & 899 \\
\hline \multicolumn{5}{|l|}{ Panel C. Baseline Survey } \\
\hline Lives with mother & $\begin{array}{c}0.92 \\
(0.28)\end{array}$ & $\begin{array}{c}0.89 \\
(0.32)\end{array}$ & 0.12 & 1123 \\
\hline Lives with father & $\begin{array}{c}0.58 \\
(0.49)\end{array}$ & $\begin{array}{c}0.58 \\
(0.49)\end{array}$ & 0.90 & 1123 \\
\hline $\begin{array}{l}\text { Hours of computer use (at school and } \\
\text { outside school) }\end{array}$ & $\begin{array}{c}3.57 \\
(5.04)\end{array}$ & $\begin{array}{l}3.85 \\
(6.37)\end{array}$ & 0.45 & 979 \\
\hline $\begin{array}{l}\text { Do your parents have rules for how } \\
\text { much TV you watch? }\end{array}$ & $\begin{array}{c}0.79 \\
(0.41)\end{array}$ & $\begin{array}{c}0.74 \\
(0.44)\end{array}$ & $0.04^{* *}$ & 1110 \\
\hline Do you have a curfew? & $\begin{array}{c}0.84 \\
(0.37)\end{array}$ & $\begin{array}{c}0.81 \\
(0.39)\end{array}$ & 0.17 & 1076 \\
\hline $\begin{array}{l}\text { Do you usually eat dinner with your } \\
\text { parents? }\end{array}$ & $\begin{array}{c}0.90 \\
(0.31)\end{array}$ & $\begin{array}{c}0.87 \\
(0.34)\end{array}$ & 0.11 & 1112 \\
\hline Does your mother have job? ${ }^{4}$ & $\begin{array}{c}0.47 \\
(0.50)\end{array}$ & $\begin{array}{l}0.46 \\
(0.50)\end{array}$ & 0.68 & 990 \\
\hline Does your father have a job? & $\begin{array}{c}0.73 \\
(0.44)\end{array}$ & $\begin{array}{c}0.70 \\
(0.46)\end{array}$ & 0.36 & 632 \\
\hline
\end{tabular}

Notes: In Columns 1 and 2, means reported with standard errors in parentheses. Column 3 reports the p-value for the t-test for the equality of means. ***,** * indicates significance at 1, 5 and $10 \%$.

${ }^{1}$ Omitted ethnicity category is "not reported."

${ }^{2}$ This is the highest education level of either parent (which is the measure most schools in our sample collected).

${ }^{3}$ Academic subjects include math, science, English, social studies, and computers.

${ }^{4}$ The variables for mother's and father's job is reported only for households in which the given parent lives in the household. 
Table 2. Effect of Program on Computer Ownership and Usage

(1)

\section{)} (2)

2)

Owns a

Computer
(3)

(4)

Hours of Computer

(5)

(6)

\section{Panel A. Computer Ownership and Usage}

$\begin{array}{lcccccc}\text { Treatment } & 0.55 & 0.25 & 2.48 & 2.55 & -0.01 & -0.06 \\ & (0.03)^{* * *} & (0.03)^{* * *} & (0.48)^{* * *} & (0.32)^{* * *} & (0.17) & (0.29) \\ \text { Observations } & 852 & 831 & 755 & 755 & 755 & 755 \\ \text { Control mean } & 0.26 & 0.17 & 4.23 & 0.76 & 1.59 & 1.89 \\ \text { Control std. dev. } & 0.44 & 0.38 & 5.22 & 2.31 & 2.32 & 3.98\end{array}$

Hours of Computer Use Per Week

\begin{tabular}{ccccc}
\hline Schoolwork & Email & Games & $\begin{array}{c}\text { Net- } \\
\text { working }\end{array}$ & Other $\begin{array}{c}\text { Do you have a social } \\
\text { networking page? }\end{array}$ \\
\hline
\end{tabular}

\section{Panel B. Activities on Computer}

\begin{tabular}{|c|c|c|c|c|c|c|}
\hline Treatment & $\begin{array}{c}0.80 \\
(0.25)^{* * *}\end{array}$ & $\begin{array}{c}0.42 \\
(0.12)^{* * *}\end{array}$ & $\begin{array}{c}0.80 \\
(0.22)^{* * *}\end{array}$ & $\begin{array}{c}0.57 \\
(0.18)^{* * *}\end{array}$ & $\begin{array}{c}0.17 \\
(0.11)\end{array}$ & $\begin{array}{c}0.07 \\
(0.04)^{*}\end{array}$ \\
\hline Observations & 671 & 671 & 671 & 671 & 671 & 692 \\
\hline Control mean & 1.89 & 0.25 & 0.84 & 0.57 & 0.62 & 0.53 \\
\hline Control std. dev. & 2.57 & 0.72 & 1.81 & 1.79 & 1.39 & 0.50 \\
\hline $\begin{array}{l}\text { Notes: Data is fro } \\
\text { We also include } \\
\text { is English, whethe } \\
\text { have rules for hov } \\
\text { observations, for } \\
\text { original variable } \\
* * * * * *\end{array}$ & $\begin{array}{l}\text { Irvey comp } \\
\text { gender, } e \\
\text { st an immid } \\
\text { we create } \\
\text { the coeffic }\end{array}$ & $\begin{array}{l}\text { by students. } \\
\text { ty, grade, po } \\
\text { whether th } \\
\text {, and wheth } \\
\text { my equal to } \\
\text { are identifie }\end{array}$ & $\begin{array}{l}\text { gressions } \\
\text { tal educa } \\
\text { ther/fath } \\
\text { he mothe } \\
\text { fthe varia } \\
\text { om those }\end{array}$ & $\begin{array}{l}\text { ntrol for th } \\
\text { on, whethe } \\
\text { r lives with } \\
\text { father has } \\
\text { le is missin } \\
\text { ith non-mis }\end{array}$ & $\begin{array}{l}\text { amplin. } \\
\text { ne stude } \\
\text { e studer } \\
\text { ob. To a } \\
\text { or a stu }\end{array}$ & $\begin{array}{l}\text { school*y } \\
\text { ary lang } \\
\text { er paren } \\
\text { oping } \\
\text { code the }\end{array}$ \\
\hline
\end{tabular}


Table 3. Grades

\begin{tabular}{|c|c|c|c|c|c|c|c|c|}
\hline & $(1)$ & $(2)$ & (3) & $(4)$ & (5) & (6) & (7) & $(8)$ \\
\hline & \multicolumn{2}{|c|}{ Grades $^{1}$} & \multicolumn{2}{|c|}{$\begin{array}{l}\text { Indicator for passing } \\
\text { class }\end{array}$} & & & & \\
\hline & All subjects & $\begin{array}{l}\text { Academic } \\
\text { Subjects }^{2}\end{array}$ & All subjects & $\begin{array}{l}\text { Academic } \\
\text { Subjects }\end{array}$ & & & & \\
\hline \multicolumn{9}{|l|}{ Panel A. Class Grades } \\
\hline Treatment & $\begin{array}{l}-0.02 \\
(0.04)\end{array}$ & $\begin{array}{c}0.03 \\
(0.04)\end{array}$ & $\begin{array}{c}0.00 \\
(0.01)\end{array}$ & $\begin{array}{c}0.00 \\
(0.01)\end{array}$ & & & & \\
\hline Quarter $1 \mathrm{GPA}^{3}$ & $\begin{array}{c}0.75 \\
(0.02)^{* * *}\end{array}$ & $\begin{array}{c}0.70 \\
(0.02)^{* * *}\end{array}$ & $\begin{array}{c}0.13 \\
(0.01)^{* * *}\end{array}$ & $\begin{array}{c}0.12 \\
(0.01)^{* * *}\end{array}$ & & & & \\
\hline Observations & 11514 & 7820 & 11514 & 7820 & & & & \\
\hline Number of students & 1036 & 1035 & 1036 & 1035 & & & & \\
\hline Control mean & 2.47 & 2.26 & 0.88 & 0.86 & & & & \\
\hline \multirow[t]{3}{*}{ Control std. dev. } & 1.36 & 1.36 & 0.33 & 0.35 & & & & \\
\hline & \multicolumn{4}{|c|}{ Grade } & \multicolumn{4}{|c|}{ Indicator for passing class } \\
\hline & Math & $\begin{array}{l}\text { English / } \\
\text { Reading }\end{array}$ & $\begin{array}{c}\text { Social } \\
\text { Studies }\end{array}$ & Science & Math & $\begin{array}{l}\text { English / } \\
\text { Reading }\end{array}$ & $\begin{array}{l}\text { Social } \\
\text { Studies }\end{array}$ & Science \\
\hline Panel B. Class Grades by Subject & & & & & & & & \\
\hline Treatment & $\begin{array}{c}0.02 \\
(0.06)\end{array}$ & $\begin{array}{c}-0.09 \\
(0.06)\end{array}$ & $\begin{array}{c}0.10 \\
(0.06)\end{array}$ & $\begin{array}{c}0.08 \\
(0.06)\end{array}$ & $\begin{array}{c}0.01 \\
(0.02)\end{array}$ & $\begin{array}{l}-0.02 \\
(0.02)\end{array}$ & $\begin{array}{c}0.02 \\
(0.02)\end{array}$ & $\begin{array}{l}-0.01 \\
(0.02)\end{array}$ \\
\hline Quarter 1 GPA in academic subjects & $\begin{array}{c}0.69 \\
(0.03)^{* * *}\end{array}$ & $\begin{array}{c}0.65 \\
(0.03)^{* * *}\end{array}$ & $\begin{array}{c}0.76 \\
(0.03)^{* * *}\end{array}$ & $\begin{array}{c}0.73 \\
(0.03)^{* * *}\end{array}$ & $\begin{array}{c}0.15 \\
(0.01)^{* * *}\end{array}$ & $\begin{array}{c}0.11 \\
(0.01)^{* * *}\end{array}$ & $\begin{array}{c}0.12 \\
(0.01)^{* * *}\end{array}$ & $\begin{array}{c}0.13 \\
(0.01)^{* * *}\end{array}$ \\
\hline Observations & 1886 & 2121 & 1784 & 1895 & 1886 & 2121 & 1784 & 1895 \\
\hline Number of students ${ }^{4}$ & 969 & 903 & 921 & 960 & 969 & 903 & 921 & 960 \\
\hline Control mean & 1.99 & 2.46 & 2.28 & 2.24 & 0.82 & 0.88 & 0.85 & 0.86 \\
\hline Control std. dev. & 1.35 & 1.32 & 1.36 & 1.36 & 0.38 & 0.32 & 0.35 & 0.35 \\
\hline
\end{tabular}

Notes: Regressions restricted to 2nd semester. All regressions control for subject and for whether the class is in the 3rd or 4 th quarter. Regressions also include controls for the sampling strata (school*year) and the same controls as in Table 2.

***, **, * indicates significance at 1, 5 and $10 \%$.

${ }^{1}$ Grades are coded as A-4, B-3, C-2, D-1, F-0. +/- modifiers are set equal to 0.33 points. Passing is defined as D- or higher.

2 "Academic subjects" include Math, English, Social Studies, Science, and Computers.

${ }^{3}$ The quarter 1 GPA is for all subjects in Columns 1 and 3, and for academic subjects only in Columns 2 and 4.

${ }^{4}$ Note that a small number of students take multiple science classes in the same term. A larger number of students take multiple English classes concurrently (for example, English and Reading). 
Table 4. California STAR Test

(1)

(2)

(3)

(4)

English / Language Arts

Math

Panel A. Standardized Score

Treatment

$-0.05$

(0.06)

$-0.05$

(0.05)

0.69

Prior year's test score

$(0.03)^{* * *}$

961

961

0.00

0.00

1.00

0.00

$-0.07$

(0.06)

$-0.06$

$(0.05)$

0.62

Observations

1.00

1.00

$(0.03)^{* * *}$

914

Control std. dev.

$\begin{array}{cccc}0.00 & 0.00 & -0.02 & -0.02 \\ (0.03) & (0.02) & (0.03) & (0.03) \\ & 0.25 & & 0.26 \\ & (0.01)^{* * *} & & (0.01)^{* * *} \\ 961 & 961 & 914 & 914 \\ 0.29 & 0.29 & 0.30 & 0.30 \\ 0.46 & 0.46 & 0.46 & 0.46\end{array}$

\section{Panel B. Indicator for Proficiency ${ }^{1}$}

Treatment

Cater

Prior year's test score

0.46

0.00

1.00

Observations

Control mean

Control std. dev.

Notes: Test scores are normalized to have mean 0 and standard deviation 1. See the notes to Table 2 for the list of controls. Regressions also control for the sampling strata (school*year). To avoid dropping observations, for each control variable (including the prior year's test score), we create a dummy equal to 1 if the variable is missing for a student and code the original variable as a 0 (so that the coefficients are identified from those with non-missing values).

***, **, * indicates significance at 1,5 and $10 \%$.

${ }^{1}$ This variable is coded as 1 if the student receive a 4 or 5 (out of 5) on the test, and 0 otherwise.

Table 5. Administrative Outcomes

\begin{tabular}{lccccc}
\hline \hline & $\begin{array}{c}(1) \\
\text { Total credits } \\
\text { in 3rd } \\
\text { quarter }\end{array}$ & $\begin{array}{c}\text { Total credits } \\
\text { in 4th } \\
\text { quarter }\end{array}$ & $\begin{array}{c}(3) \\
\text { Unexcused } \\
\text { Absences }\end{array}$ & $\begin{array}{c}\text { (4) } \\
\text { Number of } \\
\text { Tardies }\end{array}$ & $\begin{array}{c}\text { Still enrolled at } \\
\text { End of Year }\end{array}$ \\
\cline { 2 - 6 } Treatment & 0.04 & -0.03 & -0.37 & -0.21 & 0.01 \\
Observations & $(0.09)$ & $(0.10)$ & $(0.38)$ & $(0.93)$ & $(0.02)$ \\
R-squared & 1123 & 1123 & 1104 & 1104 & 1123 \\
Control mean & 0.40 & 0.35 & 0.34 & 0.24 & 0.20 \\
Control std. dev. & 5.36 & 5.48 & 4.94 & 11.53 & 0.88 \\
\hline
\end{tabular}

Notes: Regressions acontrol for the sampling strata (school*year), and the same list of control as Table 2. The variable "Left School by End of Year" is coded as a 1 if the student had no grade data in the 4th quarter. ***,**, *indicates significance at 1, 5 and $10 \%$. 
Table 6. Effort in School, Software Use, and Computer Knowledge

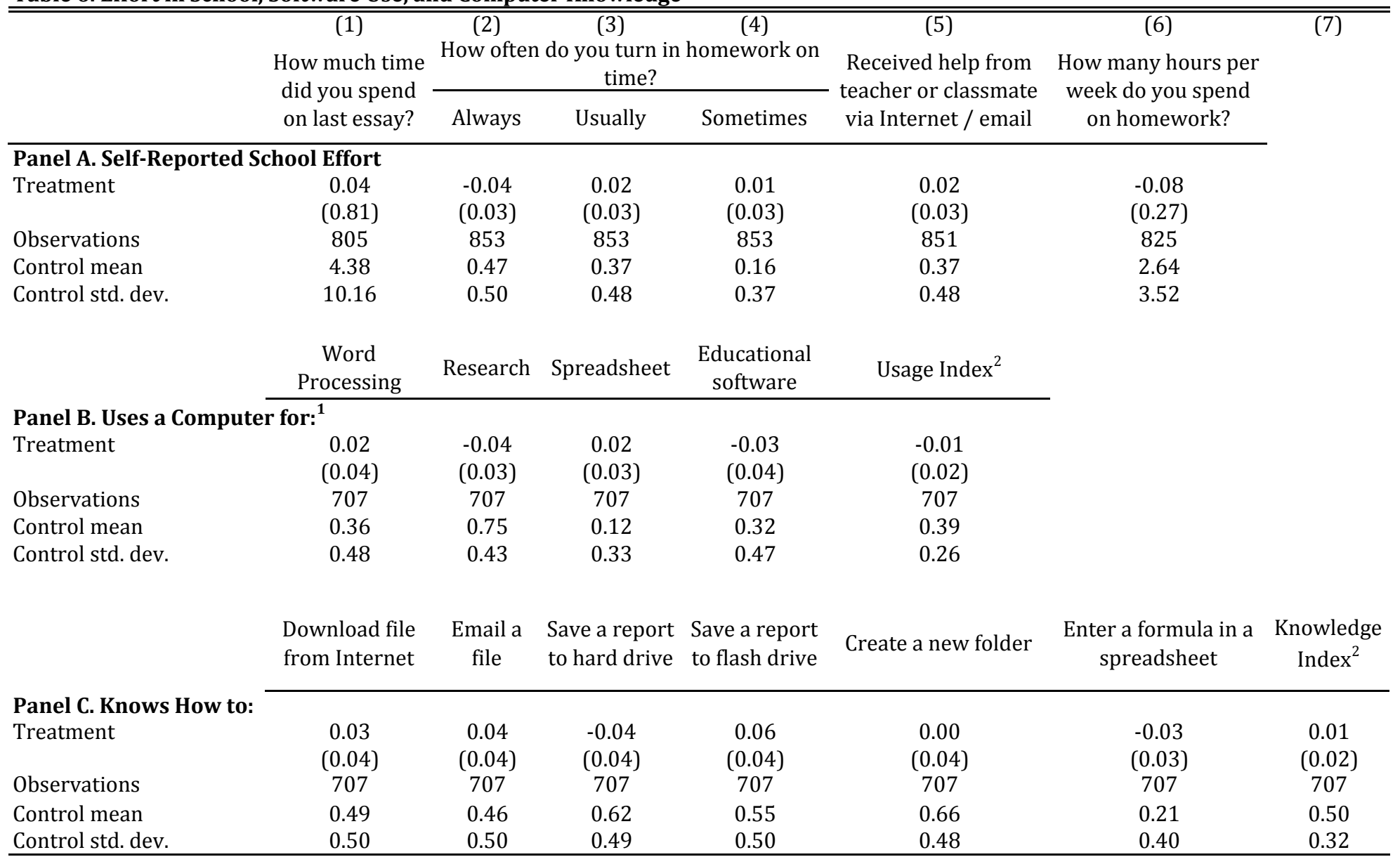

Notes: Data is from follow-up survey completed by students. See the notes to Table 2 for the list of controls.

***, **, * indicates significance at 1, 5 and $10 \%$.

${ }^{1}$ The questions in Panels B and C were only asked in the 2nd year of the program (2009-2010).

${ }^{2}$ For both knowledge and usage, the index sums the number of questions for which the student reported "yes" and divides by the total number of questions. 


\begin{tabular}{lccccc} 
Weekly Hours & Weekly Hours Computer & Hours per week & Grades in \\
Computer Use & $\begin{array}{c}\text { Use on Video Games and } \\
\text { Social Networking }\end{array}$ & $\begin{array}{c}\text { spent on } \\
\text { homework }\end{array}$ & $\begin{array}{c}\text { Academic } \\
\text { Subjects }\end{array}$ & English & Math \\
\hline
\end{tabular}

\section{Panel A. TV Rules}

Treatment

Parents have rules for TV at baseline

$\begin{array}{cc}2.96 & 2.28 \\ (0.95)^{* * *} & (0.65)^{* * *} \\ -0.28 & -0.12 \\ (0.83) & (0.56) \\ -0.65 & -1.21 \\ (1.09) & (0.75) \\ 0.01^{* * *} & 0.01^{* * *} \\ 0.75 & 0.74 \\ 755 & 671 \\ 755 & 671 \\ 4.23 & 1.41 \\ 5.22 & 3.01\end{array}$

-0.10
$(0.55)$
0.30
$(0.47)$
0.03
$(0.63)$
0.82
0.75
825
825
2.64
3.52

0.02
$(0.09)$
0.02
$(0.08)$
0.01
$(0.10)$
0.57
0.75
7820
1035
2.26
1.36

$-0.06$

0.05

(0.09)

(0.10)

Parents have TV rules at baseline * treatment

$p$-value for interaction + main treatment effect

Mean of interacted variable

Observations

Control mean of dependent variable

5.22

\section{Panel B. Curfew}

Treatment

$\begin{array}{cc}4.02 & 2.85 \\ (1.10)^{* * *} & (0.73)^{* * *} \\ 0.08 & -0.08 \\ (0.95) & (0.64) \\ -1.60 & -1.67 \\ (1.22) & (0.81)^{* *} \\ 0.01^{* * *} & 0.01^{* * *} \\ 0.82 & 0.81 \\ 723 & 641 \\ 723 & 641 \\ 4.03 & 1.29 \\ 4.20 & 2.12\end{array}$

-0.28
$(0.64)$
-0.74
$(0.55)$
0.28
$(0.72)$
1.00
0.80
788
788
2.68
3.56

-0.02
$(0.10)$
-0.08
$(0.09)$
0.05
$(0.11)$
0.56
0.83
7501
991
2.25
1.35

$-0.15$

$-0.22$

Has curfew at baseline

2.12

(0.08)

0.02

(0.09)

0.01

(0.11) (0.12)

$0.38 \quad 0.11$

$0.75 \quad 0.75$

$961 \quad 914$

$961 \quad 914$

$0.00 \quad 0.00$

$1.00 \quad 1.00$

Has curfew at baseline * treatment

$p$-value for interaction + main treatment effect

3.56

(0.11)

$(0.12)^{*}$

$-0.08 \quad 0.02$

(0.09) (0.10)

$0.13 \quad 0.17$

(0.12) (0.14)

$0.62 \quad 0.38$

$0.82 \quad 0.82$

$926 \quad 880$

$926 \quad 880$

Number of students 723

Control mean of dependent variable
Control std. dev.

$2.12 \quad 3.56 \quad 1.35$

$0.01 \quad 0.01$

$1.00 \quad 1.00$

Notes: All regressions include controls for the sampling strata (school*year) and the same controls as in Table 2 GPA and test score regressions control for the pretreatment level of the given variable. Mean and median reported baseline video game playing are 1.8 and 1 hours per week.

***, **, * indicates significance at 1, 5 and 10\%.

${ }^{1}$ Course are restricted to "Academic subjects" (Math, English, Social Studies, Science, and Computers). 
Table 8. Heterogeneity by Baseline Propensity to Use Computers for Non-Educational Purposes

\begin{tabular}{|c|c|c|c|c|c|c|}
\hline & \multirow{3}{*}{$\begin{array}{l}\text { Weekly Hours } \\
\text { Computer Use }\end{array}$} & \multirow{3}{*}{$\begin{array}{c}(2) \\
\text { Weekly Hours Computer } \\
\text { Use on Video Games and } \\
\text { Social Networking }\end{array}$} & \multirow{3}{*}{$\begin{array}{c}\text { (3) } \\
\text { Hours per week } \\
\text { spent on } \\
\text { homework }\end{array}$} & \multirow{3}{*}{$\begin{array}{c}(4) \\
\text { Grades in } \\
\text { Academic } \\
\text { Subjects }^{1}\end{array}$} & \multirow{2}{*}{\multicolumn{2}{|c|}{$\begin{array}{c}(5) \\
\text { Standardized STAR score }\end{array}$}} \\
\hline & & & & & & \\
\hline & & & & & English & Math \\
\hline \multicolumn{7}{|l|}{ Panel A. Has social networking page } \\
\hline \multirow[t]{2}{*}{ Treatment } & 2.19 & 1.24 & -0.38 & -0.04 & -0.08 & -0.09 \\
\hline & $(0.61)^{* * *}$ & $(0.42)^{* * *}$ & $(0.35)$ & $(0.05)$ & $(0.06)$ & $(0.07)$ \\
\hline \multirow[t]{2}{*}{ Has social networking page at baseline } & -0.55 & 0.19 & -0.54 & -0.30 & -0.04 & -0.09 \\
\hline & $(0.73)$ & $(0.51)$ & $(0.42)$ & $(0.07)^{* * *}$ & $(0.07)$ & $(0.08)$ \\
\hline Has social networking page at baseline & 1.12 & 0.47 & 0.85 & 0.21 & 0.08 & 0.08 \\
\hline * treatment & $(1.00)$ & $(0.69)$ & $(0.57)$ & $(0.09)^{* *}$ & $(0.10)$ & $(0.11)$ \\
\hline$p$-value for interaction + main treatment effect & $0.01^{* * *}$ & $0.01^{* * *}$ & 0.30 & $0.03^{* *}$ & 1.00 & 0.91 \\
\hline Mean of interacted variable & 0.38 & 0.38 & 0.38 & 0.40 & 0.39 & 0.40 \\
\hline Observations & 743 & 660 & 813 & 7729 & 951 & 905 \\
\hline Number of students & 743 & 660 & 813 & 1023 & 951 & 905 \\
\hline Control mean of dependent variable & 4.17 & 1.39 & 2.67 & 2.25 & 0.01 & 0.01 \\
\hline Control std. dev. & 5.05 & 2.97 & 3.54 & 1.36 & 1.00 & 1.00 \\
\hline \multicolumn{7}{|l|}{ Panel B. Video Game Playing } \\
\hline \multirow[t]{2}{*}{ Treatment } & 2.66 & 1.61 & -0.46 & -0.03 & -0.07 & -0.04 \\
\hline & $(0.79)^{* * *}$ & $(0.55)^{* * *}$ & $(0.45)$ & $(0.07)$ & $(0.07)$ & $(0.08)$ \\
\hline \multirow[t]{2}{*}{ Played video games at baseline } & 1.18 & 0.47 & 0.24 & -0.13 & -0.02 & -0.03 \\
\hline & $(0.71)^{*}$ & $(0.49)$ & $(0.41)$ & $(0.06)^{* *}$ & $(0.07)$ & $(0.08)$ \\
\hline \multirow[t]{2}{*}{ Played video games at baseline $*$ treatment } & -0.12 & -0.26 & 0.59 & 0.10 & 0.02 & -0.05 \\
\hline & $(1.00)$ & $(0.69)$ & $(0.57)$ & $(0.09)$ & $(0.10)$ & $(0.11)$ \\
\hline$p$-value for interaction + main treatment effect & $0.01^{* * *}$ & $0.01^{* * *}$ & 0.70 & 0.27 & 0.45 & 0.15 \\
\hline Mean of interacted variable & 0.63 & 0.63 & 0.62 & 0.61 & 0.61 & 0.61 \\
\hline Observations & 742 & 660 & 810 & 7663 & 944 & 897 \\
\hline Number of students & 742 & 660 & 810 & 1014 & 944 & 897 \\
\hline Control mean & 4.15 & 1.35 & 2.65 & 2.26 & 0.01 & 0.02 \\
\hline Control std. dev. & 5.04 & 2.90 & 3.54 & 1.36 & 1.00 & 1.00 \\
\hline
\end{tabular}

Notes: All regressions include controls for the sampling strata (school*year) and the same controls as in Table 2. GPA and test score regressions control for the pretreatment level of the given variable. Mean and median reported baseline video game playing are 1.8 and 1 hours per week.

***, **, * indicates significance at 1, 5 and $10 \%$.

${ }^{1}$ Course are restricted to "Academic subjects" (Math, English, Social Studies, Science, and Computers). 
Of those completing survey:

Number of students without a computer

Of those without a computer:

Number of students returning baseline survey

Notes:

${ }^{1}$ Percentages (Columns 3 and 5) exclude one school which did not provide figures on the total number of eligible children. 


\begin{tabular}{|c|c|c|c|c|}
\hline & (1) & (2) & (3) & $(4)$ \\
\hline & $\begin{array}{c}\text { Appears in } \\
\text { baseline } \\
\text { adminstrative } \\
\text { dataset }\end{array}$ & $\begin{array}{c}\text { Appears in } \\
\text { follow-up } \\
\text { administrative } \\
\text { dataset }\end{array}$ & $\begin{array}{l}\text { Appears in } \\
\text { grade dataset }\end{array}$ & \\
\hline \multicolumn{5}{|c|}{ Panel A. Administrative Outcomes } \\
\hline Treatment & $\begin{array}{c}0.00 \\
(0.01)\end{array}$ & $\begin{array}{c}0.00 \\
(0.01)\end{array}$ & $\begin{array}{c}-0.01 \\
(0.01)\end{array}$ & \\
\hline Observations & 1123 & 1123 & 1123 & \\
\hline Sample & Full & Full & Full & \\
\hline \multirow[t]{2}{*}{ Control mean } & 0.99 & 0.99 & 0.99 & \\
\hline & $\begin{array}{l}\text { Has STAR } \\
\text { scores }\end{array}$ & $\begin{array}{c}\text { Returned } \\
\text { follow-up } \\
\text { survey }\end{array}$ & $\begin{array}{l}\text { Has STAR } \\
\text { scores }\end{array}$ & $\begin{array}{c}\text { Returned } \\
\text { follow-up } \\
\text { survey }\end{array}$ \\
\hline \multicolumn{5}{|c|}{ Panel B. Test Scores and Follow-up Survey } \\
\hline Treatment & $\begin{array}{c}0.01 \\
(0.02)\end{array}$ & $\begin{array}{c}0.02 \\
(0.02)\end{array}$ & $\begin{array}{l}-0.01 \\
(0.01)\end{array}$ & $\begin{array}{c}0.00 \\
(0.02)\end{array}$ \\
\hline Observations & 1123 & 1123 & 992 & 992 \\
\hline Sample & Full & Full & \multicolumn{2}{|c|}{$\begin{array}{l}\text { Restricted to those still } \\
\text { enrolled at end of year }\end{array}$} \\
\hline Control mean & 0.87 & 0.76 & 0.96 & 0.84 \\
\hline
\end{tabular}


Appendix Table A3. Heterogeneity by pre-treatment performance

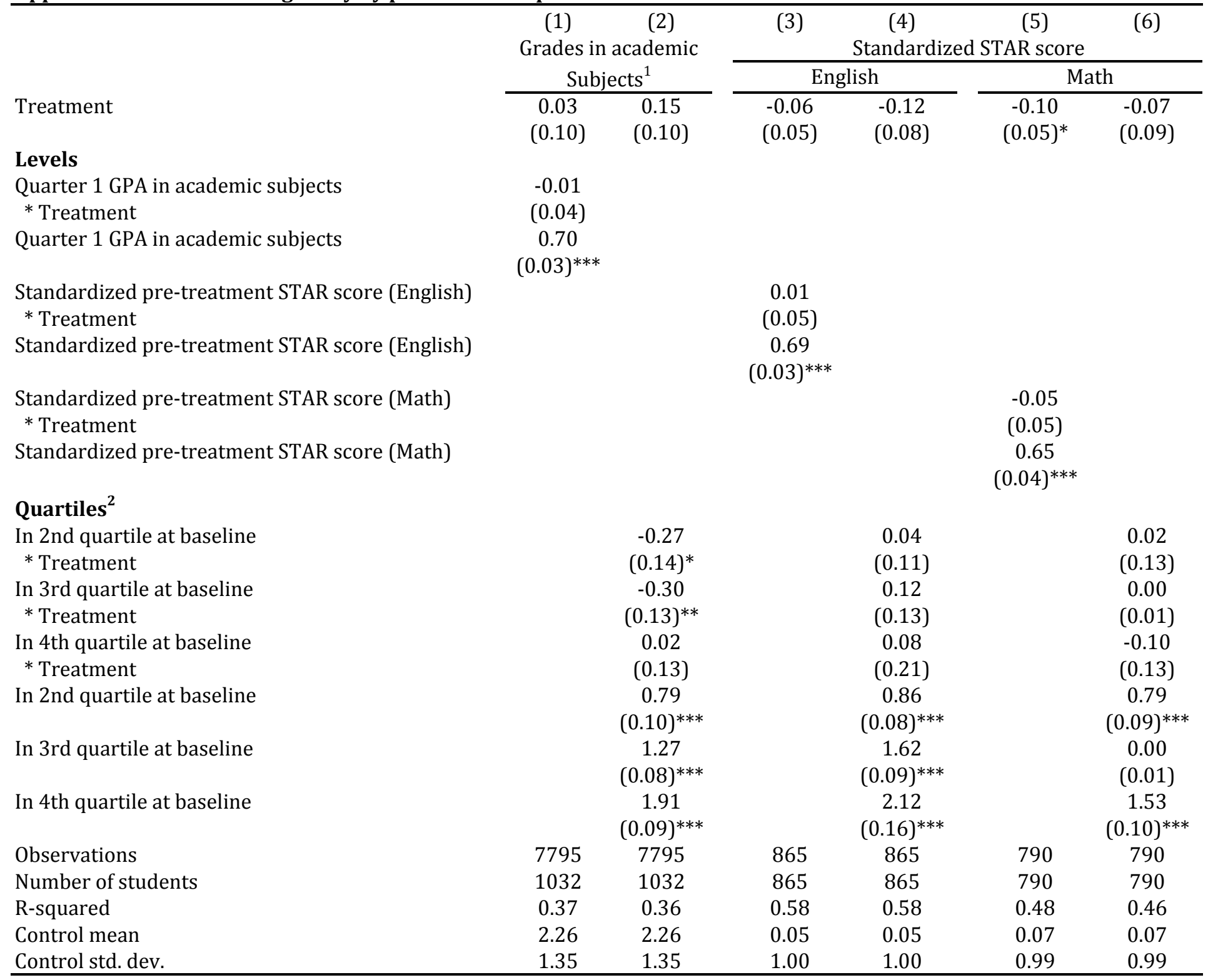

Notes: All regressions include controls for the sampling strata (school*year) and the same controls as in Table 2.

***, **, *indicates significance at 1,5 and $10 \%$.

1 "Academic subjects" include Math, English, Social Studies, Science, and Computers.

${ }^{2}$ The quartiles are for the pre-treatment levels of the dependent variables (quarter 1 GPA in Columns 1-2, pre-treatment English STAR score in Columns 3-4, and pre-treatment Math STAR score in Columns 5-6). 
Appendix Table A4. Heterogeneity by demographic characteristics

\begin{tabular}{|c|c|c|c|c|c|c|c|c|c|}
\hline & (1) & (2) & (3) & (4) & $(5)$ & $(6)$ & (7) & $\overline{(8)}$ & $\overline{(9)}$ \\
\hline & \multirow{2}{*}{\multicolumn{3}{|c|}{ Grades in Academic Subjects ${ }^{1}$}} & \multicolumn{6}{|c|}{ Standardized STAR score } \\
\hline & & & & \multicolumn{3}{|c|}{ English } & \multicolumn{3}{|c|}{ Math } \\
\hline Treatment & $\begin{array}{c}0.17 \\
(0.09)^{*}\end{array}$ & $\begin{array}{c}0.01 \\
(0.06)\end{array}$ & $\begin{array}{c}0.00 \\
(0.12)\end{array}$ & $\begin{array}{l}-0.02 \\
(0.11)\end{array}$ & $\begin{array}{c}0.00 \\
(0.07)\end{array}$ & $\begin{array}{c}0.17 \\
(0.15)\end{array}$ & $\begin{array}{l}-0.12 \\
(0.12)\end{array}$ & $\begin{array}{c}-0.13 \\
(0.07)^{*}\end{array}$ & $\begin{array}{l}-0.05 \\
(0.16)\end{array}$ \\
\hline Quarter 1 GPA in academic subjects & $\begin{array}{c}0.70 \\
(0.02)^{* * *}\end{array}$ & $\begin{array}{c}0.70 \\
(0.02)^{* * *}\end{array}$ & $\begin{array}{c}0.70 \\
(0.02)^{* * *}\end{array}$ & & & & & & \\
\hline Pre-treatment STAR score (English) & & & & $\begin{array}{c}0.69 \\
(0.03)^{* * *}\end{array}$ & $\begin{array}{c}0.69 \\
(0.03)^{* * *}\end{array}$ & $\begin{array}{c}0.69 \\
(0.03)^{* * *}\end{array}$ & & & \\
\hline Pre-treatment STAR score (Math) & & & & & & & $\begin{array}{c}0.62 \\
(0.03)^{* * *}\end{array}$ & $\begin{array}{c}0.62 \\
(0.03)^{* * *}\end{array}$ & $\begin{array}{c}0.62 \\
(0.03)^{* * *}\end{array}$ \\
\hline Minority student & $\begin{array}{l}-0.13 \\
(0.16)\end{array}$ & & & $\begin{array}{c}0.00 \\
(0.18)\end{array}$ & & & $\begin{array}{c}0.01 \\
(0.19)\end{array}$ & & \\
\hline Minority student $*$ treatment & $\begin{array}{c}-0.17 \\
(0.11)^{*}\end{array}$ & & & $\begin{array}{l}-0.04 \\
(0.12)\end{array}$ & & & $\begin{array}{c}0.08 \\
(0.13)\end{array}$ & & \\
\hline Female & & $\begin{array}{c}0.12 \\
(0.06)^{*}\end{array}$ & & & $\begin{array}{c}0.14 \\
(0.07)^{* *}\end{array}$ & & & $\begin{array}{l}-0.11 \\
(0.07)\end{array}$ & \\
\hline Female * treatment & & $\begin{array}{c}0.04 \\
(0.09)\end{array}$ & & & $\begin{array}{l}-0.10 \\
(0.09)\end{array}$ & & & $\begin{array}{c}0.14 \\
(0.10)\end{array}$ & \\
\hline Grade 7 & & & $\begin{array}{c}1.12 \\
(0.54)^{* *}\end{array}$ & & & $\begin{array}{c}0.04 \\
(0.14)\end{array}$ & & & $\begin{array}{c}0.08 \\
(0.86)\end{array}$ \\
\hline Grade $7 *$ treatment & & & $\begin{array}{c}0.01 \\
(0.14)\end{array}$ & & & $\begin{array}{c}-0.24 \\
(0.16)\end{array}$ & & & $\begin{array}{c}-0.10 \\
(0.18)\end{array}$ \\
\hline Grade 8 & & & $\begin{array}{c}1.17 \\
(0.53)^{* *}\end{array}$ & & & $\begin{array}{c}0.15 \\
(0.16)\end{array}$ & & & $\begin{array}{c}0.10 \\
(0.86)\end{array}$ \\
\hline Grade $8 *$ treatment & & & $\begin{array}{c}0.04 \\
(0.14)\end{array}$ & & & $\begin{array}{c}-0.27 \\
(0.17)\end{array}$ & & & $\begin{array}{c}0.06 \\
(0.18)\end{array}$ \\
\hline$p$-value for interaction + main treatment effect & 0.94 & 0.47 & - & 0.24 & 0.13 & - & 0.43 & 0.87 & - \\
\hline Mean of interacted variable & 0.83 & 0.50 & - & 0.83 & 0.51 & - & 0.83 & 0.51 & - \\
\hline Observations & 7792 & 7820 & 7820 & 958 & 961 & 961 & 913 & 914 & 914 \\
\hline Number of students & 1031 & 1035 & 1035 & 958 & 961 & 961 & 913 & 914 & 914 \\
\hline Control mean & 2.25 & 2.26 & 2.26 & 0.00 & 0.00 & 0.00 & 0.00 & 0.00 & 0.00 \\
\hline Control std. dev. & 1.36 & 1.36 & 1.36 & 1.00 & 1.00 & 1.00 & 1.00 & 1.00 & 1.00 \\
\hline
\end{tabular}

